$12-2009$

\title{
You've Got Your Mother's Laugh: What Bankruptcy Mediation Can Learn from the Her/History of Divorce and Child Custody Mediation
}

Nancy A. Welsh

Texas A\&M University School of Law, nwelsh@law.tamu.edu

Follow this and additional works at: https://scholarship.law.tamu.edu/facscholar

Part of the Bankruptcy Law Commons, and the Dispute Resolution and Arbitration Commons

\section{Recommended Citation}

Nancy A. Welsh, You've Got Your Mother's Laugh: What Bankruptcy Mediation Can Learn from the Her/ History of Divorce and Child Custody Mediation, 17 Am. Bankr. Inst. L. Rev. 427 (2009).

Available at: https://scholarship.law.tamu.edu/facscholar/951

This Article is brought to you for free and open access by Texas A\&M Law Scholarship. It has been accepted for inclusion in Faculty Scholarship by an authorized administrator of Texas A\&M Law Scholarship. For more information, please contact aretteen@law.tamu.edu. 


\title{
YOU'VE GOT YOUR MOTHER'S LAUGH: WHAT BANKRUPTCY MEDIATION CAN LEARN FROM THE HER/HISTORY OF DIVORCE AND CHILD CUSTODY MEDIATION
}

\author{
NANCY A. WELSH ${ }^{*}$
}

\begin{abstract}
Due to our current deep economic woes, growing bankruptcy filings, and apparent legislative unwillingness to expand the number of judges, bankruptcy courts are exploring the use of mediation to help resolve adversary proceedings, negotiate elements of reorganizations, and deal with claims that cannot be heard directly in bankruptcy proceedings. ${ }^{1}$ There is relatively recent precedent for these uses of mediation. ${ }^{2}$ In addition, mediation advocates have been consistent in urging greater use of the process ${ }^{3}$ to reduce debtors' and claimants' costs, ${ }^{4}$ bridge the
\end{abstract}

\footnotetext{
" Professor of Law, Penn State University, Dickinson School of Law. I am deeply indebted to Kelly Towns, Christopher Demetriou and Carolina Aguilar for their assistance with the substantial research that was required for this Article. My deep thanks as well to Peter Alexander, Margaret Whiteman Greecher, Christopher Honeyman, Nancy LaMont, and Peter Salem for comments on previous drafts, to fellow panel members, Hon. Elizabeth Stong, Ralph Peeples and William Woodward, for very helpful observations and inquiries before, during and after our presentations at the symposium, and to Paul Kirgis and Elayne Greenberg at St. John's University School of Law for inviting me to participate in this symposium.

' See In re Kent, No. 07-3238, 2008 WL 5047821, at *2 (Bankr. D. Ariz. July, 25 2008) (showing parties' eventual willingness to agree "to utilize the [c]ourt's mediation program"); In re Teraforce Tech. Corp., 347 B.R. 838, 853 (Bankr. N.D. Tex. 2006) (noting successful result from court-ordered mediation); cf. In re American Capital Equip., 405 B.R. 415, 422 (Bankr. W.D. Pa. 2009) (discussing alternative dispute resolution option termed "Court Approved Distribution Procedures" allowing asbestos claim holders to enter mediation instead of litigating their claims in court). Mediation also is being used to a lesser degree for preference cases and bankruptcy appeals. See William J. Woodward, Jr., The Third Way: Mediation of Products Claims in the Piper Aircraft Trust, 17 AM. BANKR. INST. L. REv. 463, 477 (2009) (discussing reasons for "inevitably-lower rate of consensual settlement" among preference cases).

${ }^{2}$ See H. Slayton Dabney Jr. \& Dion W. Hayes, Bankruptcy Lawyers Better Tune Up Their ADR Skills: Best Products Is One Case Where Mediation Really Worked, 28 AM. BANKR. INST. J. 16, 16 (June 2009) (outlining use of mediation in Best Products liquidation following company's second chapter 11 filing and noting "failure of a claimant to participate in the mediation resulted in the disallowance and extinguishment of its claim"); Ralph R. Mabey et al., Expanding the Reach of Alternative Dispute Resolution in Bankruptcy: The Legal and Practical Bases for the Use of Mediation and the Other Forms of ADR, 46 S.C. L. REV. 1259, 1278-83 (1995) (describing court-connected bankruptcy mediation programs); Carolyn M. Penna, The Greyhound ADR Program, 204 N.Y. L.J. 114, 3 col. 1 (1990) (describing Greyhound bankruptcy and ADR program); see also General Order, Re: Procedures in Adversary Proceedings, 320 B.R. 574 (Bankr. D. Del. 2005) (providing for mandatory mediation). There has also been experimentation with the use of mediation to resolve appeals of bankruptcy decisions. See, e.g., Order in In Re: Procedures to Govern Mediation of Appeals from the United States Bankruptcy Court for this District, U.S. District Court for the District of Delaware (2004) (noting mediation of all appeals before Court as mandatory).

${ }^{3}$ See Mabey et al., supra note 2, at 1308-12 (urging greater use of mediation by bankruptcy courts).

${ }^{4}$ See, e.g., Dabney and Hayes, supra note 2, at 16 (acknowledging mediation helped unsecured creditors to receive nearly 96 cents for each dollar owed in liquidation); Penna, supra note 2, 3 col. 1 ("In a bankruptcy setting, the objective is to operate the debtor company at the lowest rates possible, in order to satisfy all creditors. Usually this means less left over for the creditor. A strong interest arises in the company finding an economical way of dealing with such obligations as damage claims.").
} 
jurisdictional and standing challenges that bankruptcies can pose, ${ }^{5}$ and offer claimants the opportunity to be heard and determine their own resolution of claims. ${ }^{6}$

At this point, though, relatively few judicial opinions discuss bankruptcy mediation or its impact. Not surprisingly, the few cases available demonstrate that bankruptcy courts generally favor the use of mediation to resolve claims and help with reorganizations. ${ }^{7}$ What is surprising, however, are the cases in which parties have attempted to use mediation to achieve unexpected and inappropriate results ${ }^{8}$ and those in which bankruptcy judges, parties and/or their lawyers apparently expect mediators to do much more than facilitate the parties' communication, negotiation and resolution. ${ }^{9}$ Sometimes, for example, judicial opinions reveal an assumption that mediators will make both procedural and substantive decisions, and that in reviewing these decisions, judges should grant substantial deference to the mediators. ${ }^{10}$ Cases such as these may suggest that the repeat players within bankruptcy - judges, lawyers, accountants, and creditors ${ }^{11}$ - do not necessarily understand how the role of the mediator is supposed to diverge in significant ways from the "traditional neutral" roles of trustee, special master, magistrate, arbitrator, examiner or judge. An appropriate response would appear to be education of the repeat players involved in bankruptcies.

On the other hand, these few cases also may signal that mediation will not always be the most appropriate vehicle for resolving issues within, or related to, bankruptcy. Instead, it may be that bankruptcy courts should both incorporate

5 See Dabney and Hayes, supra note 2, at 17 ("As to personal injury and products liability claims specifically, which the bankruptcy court lacks jurisdiction to liquidate, the debtor was able to avoid protracted discovery and litigation in non-bankruptcy courts that would have severely delayed the distribution in the Best case."); Michael Moffitt, Three Things to Be Against ("Settlement" Not Included), 78 FORDHAM L. REV. (forthcoming 2009) ("[L]itigation offers an answer to . . questions [regarding standing and joinder of claims and parties] that is legally correct, but contextually dangerous, as it excludes legitimately interested people. One of settlement's contributions is that it can ask, 'Who should be at the table?' and offer a more inclusive answer than litigation. When that occurs and a more comprehensive settlement ensues, litigation is improved because it can proceed with cases in which the risk of de facto exclusion is less serious.").

${ }^{6}$ See Dabney and Hayes, supra note 2, at 16 (explaining how non-repeat claimants such as "customers, personal injury or products liability claimants, and landlords" appreciated the "fuller hearing" available through mediation, as well as the opportunity to participate in producing an outcome).

${ }^{7}$ In re American Capital Equip., 405 B.R. 415, 422 (Bankr. W.D. Pa. 2009) (calling alternative dispute resolution "indisputably procedurally much more favorable" to court litigation).

${ }^{8}$ See infra pp. 443-44 and note 102.

9 See infra p. 444 and note 144.

${ }^{10}$ See In re Eagle-Picher Indus., 176 B.R. 143, 148 (Bankr. S.D. Ohio 1994) (explaining deference given to mediator and "no reason to question [his] judgment" because he had basis for decisions); Hickox $v$. Frieland (In re HBLS, L.P.), 01 Civ. 2025, 2001 U.S. Dist. Lexis 19112 (S.D.N.Y. Nov. 21, 2001) (applying manifest disregard standard when reviewing mediator determination).

${ }^{11}$ See Eric M. Van Horn et al., Restructuring the Misperceptions of Lawyers: Another Task for Bankruptcy Professionals, 28 AM. BANKR. INST. J. 44, 91 (Sept. 2009) ("Bona-fide bankruptcy practitioners are aware that we are repeat players."). States and state agencies also play the role of creditors. See Ralph Brubaker, Explaining Katz's New Bankruptcy Exception to State Sovereign Immunity: The Bankruptcy Power as a Federal Forum Power, 15 AM. BANKR. INST. L. REv. 95, 98 (2007) ("[S]tates and state agencies . . end up as creditors in lots of [] ways ...."). 
mediation in appropriate cases and consider expanding the availability or functions of "traditional neutrals." In the bankruptcy context, that might mean experimenting with the use of trustees and examiners in innovative procedures that include, as one part of the procedures, facilitation of dialogue and consensual resolution. ${ }^{12}$ Importantly, bankruptcy courts would need to ensure that both trustees and examiners receive training in facilitation skills and procedures that will help them manage this new function appropriately and achieve both procedural and substantive justice.

Though divorce and child custody matters may seem far-removed from bankruptcy proceedings, liquidations and reorganizations bear some intriguing superficial similarities to divorces and ongoing custody and support arrangements (perhaps better termed "familial reorganizations" for purposes of this Article). In addition, an examination of the use, abuse and evolution of mediation in this area of practice may prove useful for those who are now introducing mediation into bankruptcy. The story of divorce and child custody mediation, like most growingup stories, follows a trajectory of rejection of the status quo, successful experimentation with alternatives, enthusiastic over-promising, overuse and consequent struggles or breakdown, disappointment, reluctant recognition of limits, and finally acceptance of the need for realistic retrenchment and more restrained growth. As in the bankruptcy context, the use of certain "traditional neutrals"e.g., custody investigators, referees, conciliators-has been curtailed in many jurisdictions as the judiciary developed a preference for the consensual and flexible process of mediation. ${ }^{13}$ Recently, however, some commentators have begun to urge a closer look at the reality of today's court-connected divorce and child custody mediation programs. ${ }^{14}$ These commentators have begun advocating for a more limited use of mediation, in part due to the emergence of new, hybrid dispute resolution models that confound any bright line distinction between consensual and adjudicative approaches. ${ }^{15}$ Is it possible that bankruptcy courts, repeat players within the system and their clients could skip a couple of the stages that were involved in the evolution of divorce and child custody mediation? Only if there is

\footnotetext{
${ }_{12}^{12}$ See infra pp. 459-61.

${ }^{13}$ See Bobbi McAdoo, All Rise, the Court Is in Session: What Judges Say About Court-Connected Mediation, 22 OHIO ST. J. ON DISP. RESOL. 377, 424-25 (2006) ("There is no question that many judges perceive mediation as a dispute resolution process in which clients are given the opportunity to be active participants in negotiated solutions, and that these solutions may be better and more durable than those reached in the litigation process without mediation.").

${ }^{14}$ See Janet A. Johnson, Symposium on the Miller Commission on Matrimonial Law, 27 PACE L. REV. 539, 542-44 (2006) (explaining commentators urge closer examination of child custody proceedings because lawyers may advocate for their goal rather than child's ultimate desire); John Lande, The Movement Toward Early Case Handling in Courts and Private Dispute Resolution, 24 OHIO ST. J. ON DISP. RESOL. 81, 94-95 (2008) (stating examination of interests and needs of parties necessary to determine if litigation or dispute resolution better suits parties); Peter Salem et al., Triaging Family Court Services: The Connecticut Judicial Branch's Family Civil Intake Screen, 27 PACE. L. REV. 741, 747-48 (2006) (positing increased demand for mediators in custody disputes results in "difficult" and "frustrating" cases).

${ }_{15}$ Lande, supra note 14, at 97-98 (explaining how "mediation-evaluation hybrid process[]" creates positive results).
} 
willingness to consider the lessons of others' history (or as this Article's title suggests, "her/history"). In this Article, I will articulate my understanding of the unfolding stories ${ }^{16}$ of mediation in various parts of the civil litigation system and suggest what these stories may teach.

\section{THE INTRODUCTION OF MEDIATION INTO THE COURTS}

In recent years, many have written their own narratives of the story of mediation in the United States. ${ }^{17}$ For purposes of this Article, it is sufficient to begin by noting that mediation - a process in which a third party called a 'mediator' assists disputing parties to reach their own, consensual resolution of their dispute-has existed in the United States for a very long time. Colonists ${ }^{18}$ and Quakers ${ }^{19}$ used a mediation process to resolve disputes. Following a period of tremendous social unrest in the late 1800 s and early 1900 s-as the U.S. reconceived itself after the Civil War, morphed from a pastoral to an industrial power, and experienced disruptive and sometimes-violent labor disputes as displaced citizens and waves of immigrants dealt with major economic change and deep cultural, class and wage differences - commentators again urged the use of mediation. ${ }^{20}$ Though the process

\footnotetext{
${ }^{16}$ See Deborah R. Hensler, Our Court, Ourselves: How the Alternative Dispute Resolution Movement Is Re-Shaping Out Legal System, 108 PENN. ST. L. REV. 165, 185-88 (2003) (detailing civil litigation's trend towards mediation and positive perceptions of mediation process).

${ }^{17}$ See, e.g., id. at 167-68 (providing personal perspective on evolution of alternative dispute resolution in legal world); Carrie Menkel-Meadow, Mothers and Fathers of Invention: The Intellectual Founders of ADR, 16 OHIO ST. J. ON DISP. RESOL. 1, 2, 5 (2000) (examining early contributions of social theorists and empiricists as "'intellectual' founders of 'ADR"'); Douglas Yarn, The Death of ADR: A Cautionary Tale of Isomorphism Through Institutionalization, 108 PENN ST. L. REV. 929, 930-31 (2004) (discussing historic evolution of dispute resolution in England and analogizing it to institutionalizing alternative dispute resolution in American courts); see also JAMES J. ALFINI ET AL., MEDIATION THEORY AND PRACTICE 1-31 (2d ed. 2006); Nancy A. Welsh, The Thinning Vision of Self-Determination in Court-Connected Mediation: The Inevitable Price of Institutionalization?, 6 HARV. NEGOT. L. REV. 1, 3-4 (2001) [hereinafter Welsh, The Thinning Vision] (examining role of self-determination in alternative dispute resolution as it adapts to court culture).

${ }^{18}$ See Hensler, supra note 16, at 168-70 (recognizing Puritan settlers in New England and other utopian societies desired to avoid adversarial process).

${ }^{19}$ See Jane Calvert, Quaker CONSTITUTIONALISM AND the POlitical THOUGHT OF JOHN DiCKINSON (2009); WILliam OFFUTT, OF "GOOD LAWS" AND "GOOD MEN": LAW AND SOCIETY IN THE DELAWARE VALLEY, 1680-1710 146 (1995) (discussing Quaker "Gospel Order" dispute resolution system that put disputes in hands of small groups of community members to keep decisions away from outsiders).

${ }^{20}$ See Mary Parker Follett, Constructive Conflict, in MARY PARKER FOLlETT, PROPHET OF MANAGEMENT: A CELEBRATION OF WRITINGS FROM THE 1920S 69, 71 (Pauline Graham ed., Harvard Business School Press) (1995) (The best way to use conflict resolution in a constructive way is the concept of integration. Neither domination, in which one party wins the conflict; nor compromise, in which both parties sacrifice something toward resolution, are not the best way to make conflict work in favor of the parties. Integration is a way in which the desires of the each party can find a place and neither side has to sacrifice. Instead of dealing with what already exists, integration creates something new.); Lan Q. Hang, Online Dispute Resolution Systems: The Future of Cyberspace Law, 41 SANTA CLARA L. REV. 837, 841 (2001) ("ADR has been around since 1920. Its purpose is 'to avoid the costs, delays, and risks of a litigation system unresponsive to the needs of the busy industrial age." (citing Past, Present \& Future: Building on 70 Years of Innovation - The AAA Looks to the 2lst Century, 51 DiSP. RESOL. J. 109, 110 (1996))); Menkel-Meadow, supra note 17, at 7-10 (writing about Mary Parker Follett, she wrote: "The mother of invention saw clearly
} 
was rejected in some areas, ${ }^{21}$ the U.S. Congress ultimately chose to make mediation and arbitration central to the resolution of labor disputes. ${ }^{22}$

Then, in the late 1960s and early 1970s, during another period of social transformation ${ }^{23}$ and heightened distrust of authority, ${ }^{24}$ advocates began calling for the use of mediation to resolve community and family disputes. In 1976, judges, lawyers, and others gathered for the Pound Conference ${ }^{25}$ where Harvard Professor Frank Sander delivered a speech that is now remembered primarily for its advocacy of a "multi-door courthouse" 26 that would include mediation. By the late $1980 \mathrm{~s}$, largely in response to crushing dockets, courts were beginning to adopt mediation to resolve small claims, family, and non-family civil cases. ${ }^{27}$

Today, less than twenty years later, mediation is an integral part of the civil litigation process in the United States. ${ }^{28}$ State, federal, and administrative courts

in the 1920s that there were better ways to make use of conflict - to embrace it and to use it for more creative and innovative solutions ....").

${ }^{21}$ See Amalia D. Kessler, Deciding Against Conciliation: The Nineteenth-Century Rejection of a European Transplant and the Rise of a Distinctively American Ideal of Adversarial Adjudication, 10 THEORETICAL INQUIRIES IN L. 423, 442 (2009) (explaining how well established European tradition of conciliation courts was rejected in United States because of the concern "that these courts encouraged a discretionary exercise of authority that would reinforce power differentials and subvert the rule of law").

${ }_{22} 29$ U.S.C. $\$ 51$ (2006) (In 1913 Congress enacted legislation to facilitate mediation in labor disputes. In 1966, section 51 was repealed. By that time the National Labor Relations Act had enacted the Conciliation of Labor Disputes (1947) which states "the settlement of issues between employers and employees through collective bargaining may be advanced by making available full and adequate governmental facilities for conciliation, mediation, and voluntary arbitration to aid and encourage employers and the representatives of their employees to reach and maintain agreements ...." (quoting 29 U.S.C. $\$ 171(2006))$ ).

${ }^{23}$ For example, this period included the rise of the feminist movement and the advent of no fault divorce. See Roderick Phillips, Putting Asunder: A History of Divorce IN WeStern SOCIETy 561, 563 (1988) (noting trends in liberalization during 60's and 70's in context of feminism and important shift to no fault divorce).

${ }^{24}$ See Orlando Patterson, Liberty Against the Democratic State: on the Historical and Contemporary Sources of American Distrust, in DEMOCRACY AND TRUST 151, 182-184 (Mark E. Warren, ed., 1999) (providing data showing generational differences in levels of distrust).

${ }_{25}$ Bobbi McAdoo \& Nancy A. Welsh, Look Before You Leap and Keep on Looking: Lessons from the Institutionalization of Court-Connected Mediation, 5 NEV. L.J. 399, 401 (2004-2005) (In 1906, Dean Roscoe Pound gave a speech in St. Paul, Minnesota entitled "The Causes of Popular Dissatisfaction with the Administration of Justice." Pound suggested a wide-ranging course of court reforms. His suggestions, however, were not embraced by American Bar Association. In 1975, Chief Justice Warren Burger began a new push to finish what Pound had started. The resulting conference, jointly sponsored by the Judicial Conference of the United States, the Conference of Chief Judges, and the American Bar Association, focused on Pound's 1906 speech. To prepare for the challenges of the 21 st century, the judges, lawyers and academics assembled in St. Paul offered bold ideas for change to address the problems of justice being faced by the courts.).

${ }_{26}$ Id. at 402 (Professor Sander used the term "multi-door courthouse" to suggest a variety of dispute resolution techniques that could be fit to the needs of the dispute.); Moffitt, supra note 5 (The phrase first "appeared as a companion to a graphic on the cover of a magazine reporting on the Pound Conference.") (citing Michael L. Moffitt, Before the Big Bang: The Making of an ADR Pioneer, 22 NEGOT. J. 437, 437-38 (2006)).

27 Welsh, The Thinning Vision, supra note 17, at 20-23 (discussing courts' reasons for embracing mediation).

${ }^{28}$ See Nancy A. Welsh, Institutionalization and Professionalization, in THE HANDBOOK OF DISPUTE RESOLUTION 487, 489 (Michael L. Moffit \& Robert C. Bordone eds., 2005). 
rely on mediation to resolve cases. ${ }^{29}$ Similarly, state and federal agencies regularly use the process..$^{30}$ Lawyers who were first introduced to the process in mandatory court-connected mediation programs now counsel its use on a private, voluntary basis. ${ }^{31}$

\section{THE Different MODElS OF MEDIATION}

But what exactly is this process called "mediation?" The Uniform Mediation Act, adopted at this point by the National Conference of Commissioners on Uniform State Laws, the American Bar Association and the American Arbitration Association, as well as ten states, ${ }^{32}$ defines mediation as "a process in which a mediator facilitates communication and negotiation between parties to assist them in reaching a voluntary agreement regarding their dispute. ${ }^{133}$ The Model Standards of Conduct for Mediators describe it as "a process in which an impartial third party facilitates communication and negotiation and promotes voluntary decision making by the parties to the dispute." ${ }^{34}$ According to the Model Standards of Practice for Family and Divorce Mediation, mediation is "a process in which a mediator, an impartial third party, facilitates the resolution of family disputes by promoting the participants' voluntary agreement." ${ }^{35}$ These definitions suggest the following common characteristics: a third party; communication and negotiation between the parties; and voluntary decision-making or agreement. ${ }^{36}$

29 See, e.g., EARNESTINE RESHARD, FLORIDA MEDIATION \& ARBITRATION PROGRAMS: A COMPENDIUM $24,30-31,46-47,64-65$ (19th ed., Fiscal Year 2005-2006) (2007) (reporting Florida's use of mediation in 2005-2006 fiscal year).

${ }^{30}$ See, e.g., U.S. EQUAL EMPLOYMENT OPPORTUNITY COMMISSION, FISCAL YEAR 2008 PERFORMANCE AND ACCOUNTABILITY REPORT 8 (2008) (The Equal Employment Opportunity Commission reported that in 2007, in the Federal Sector Mediation Program, agencies reported "that there were 37,809 instances of precomplaint EEO counseling across the federal government. Of that number, the parties participated in ADR in 18,262 cases, or $48.3 \%$ of the time.").

${ }^{31}$ See Roselle L. Wissler \& Bob Dauber, Leading Horses to Water: The Impact of an ADR "Confer and Report" Rule, 26 JUST. SYS. J. 253, 263-64 (examining effects of rule requiring lawyers to use ADR processes and report results to court).

${ }^{32}$ UNIF. MEDIATION ACT REFERENCES \& ANNOTATIONS (amended 2003), 7A Pt. III U.L.A. 91 (2006 \& Supp. 2009) (noting mediation has become integral part of dispute resolution processes).

${ }^{33}$ UNIF. MEDIATION ACT $\S 2$ (1) (amended 2003) 7A Pt. III U.L.A. 105 (defining term "mediation").

${ }^{34}$ MODEL STANDARDS OF CONDUCT FOR MEDIATORS. pmbl. (2005).

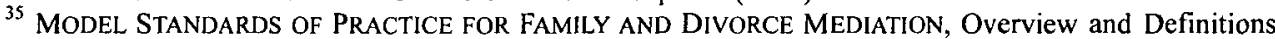
(2000); see Andrew Schepard, An Introduction to the Model Standards of Practice for Family and Divorce Mediation, 35 FAM. L.Q. 1, 3 (2001).

${ }^{36}$ Also sometimes referenced as "self-determination." See MODEL STANDARDS OF CONDUCT FOR MEDIATORS, Standard I (positing mediation is based on self-determination, requiring voluntary decisions); Tim Hedeen, Ensuring Self-Determination Through Mediation Readiness: Ethical Considerations (July 2003), http://www.mediate.com/articles/hedeenTl.cfm (discussing mediator's responsibility to ensure participation between parties); see also Jacqueline M. Nolan-Haley, Informed Consent in Mediation: A Guiding Principle for Truly Educated Decisionmaking, 74 NOTRE DAME L. REV. 775, 777, 781 (1999) (principle of informed consent helps to "promote" self-determination and empowers parties to gain control over the outcome); Welsh, The Thinning Vision, supra note 17 at 39 (explaining mediators are responsible for assisting parties reach voluntary decision). 
In practice, mediation takes many different forms. It can be facilitative, ${ }^{37}$ elicitive, ${ }^{38}$ focused on developing mutual understanding, ${ }^{39}$ therapeutic, ${ }^{40}$ or transformative, ${ }^{41}$ among other possibilities. Though there are differences among them, these models share a focus on drawing out the disputing parties, understanding their values and underlying interests, helping them to communicate fully, respectfully and productively with each other, and fostering their ability to develop their own, customized solutions. ${ }^{42}$

37 See Barnand Mayer, Facilative Mediation, in DIVORCE AND FAMILY MEDIATION: MODELS, TECHNIQUES, AND APPLICATIONS 29 (Jay Folberg, et. al eds., 2004) (discussing mediation as facilitative process); Leonard L. Riskin, Understanding Mediators' Orientations, Strategies, and Techniques: A Grid for the Perplexed, I HARV. NEGOT. L. REV. 7, 24 (1996) [hereinafter Riskin, Understanding Mediators] (discussing mediation in facilitative form where mediator clarifies and enhances communications between parties in order to help them come to decision).

${ }_{38}$ See Leonard L. Riskin, Decisionmaking in Mediation: The New Old Grid and the New New Grid System, 79 NOTRE DAME L. REV. 1, 23 (2003) [hereinafter Riskin, Decisionmaking in Mediation] (explaining mediation can be performed in elicitive fashion).

39 See Gary Friedman \& JaCk Himmelstein, Challenging Conflict: Mediation Through UNDERSTANDING (2009).

${ }^{40}$ See Marsha Kline Pruett \& Janet R. Johnston, Therapeutic Mediation with High-Conflict Parents: Effective Models and Strategies, in DIVORCE AND FAMILY MEDIATION: MODELS, TECHNIQUES, AND APPLICATIONS 95 (Jay Folberg, et. al eds., 2004) (suggesting mediators use therapeutic methods of counseling); Susan S. Silbey \& Sally E. Merry, Mediator Settlement Strategies, 8 LAW \& POL'Y 7, 12, 19 (1986) (suggesting mediation process is similar to therapeutic event); see also CHRISTOPHER W. MOORE, The Mediation Process: PractiCal Strategies for Resolving CONFLiCT 41 (2d ed. 1996) (describing other categories such as "social network mediators," "authoritative mediators," and "independent mediators"-categories that have more to do with relationship between mediator and disputants than particular types of interventions that they tend to use).

41 See Robert A. Baruch Bush \& Joseph P. Folger, The Promise of Mediation: The TRANSFORMATIVE APPROACH TO CONFLICT 46, 217-18 (Rev. ed. 2005) (describing transformative theory as based on notion people perceive conflict as interactional crisis and role of transformative-oriented mediator as assisting parties in overcoming their crisis by allowing parties to define mediation process and encouraging fully-informed voluntary resolution, rather than forcing settlement); Robert A. Baruch Bush \& Sally Ganong Pope, Changing the Quality of Conflict Interaction: The Principles and Practice of Transformative Mediation, 3 PEPP. DISP. RESOL. L.J. 67, 77 (2002) ("In the transformative mediation process, parties can recapture their sense of competence and connection, reverse the negative conflict cycle, re-establish a constructive (or at least neutral) interaction and move forward on a positive footing, with the mediator's help."); Joseph Folger, Harmony and Transformative Mediation Practice: Sustaining Ideological Differences in Purpose and Practice, 84 N.D. L. REV. 825, 844-48 (2008) (articulating four types of transformative mediation techniques that "characterize the essential elements of transformative interventions": allowing parties to control process, mediator's maintenance of non-directive role, encouraging parties' expression and examination of differences, and supporting parties' transformations toward enlightenment and self-empowerment); Tina Nabatchi \& Lisa B. Bingham, Transformative Mediation in the USPS Redress Program: Observations of ADR Specialists, 18 HOFSTRA LAB. \& EMP. L. J. 399, 401-02 (2001) (examining transformative mediation in employment setting as viable alternative to traditional adversarial-based process and as vehicle for parties to seize greater control over their own conflicts and learn how to effectively manage future conflicts).

${ }^{42}$ See Leonard L. Riskin \& Nancy A. Welsh, Is That All There Is?: The "Problem" in Court-Oriented Mediation, 15 GEO. MASON L. REV. 863, 869 (2008) (discussing power of mediation to facilitate respectful and productive cooperation among parties, enable parties' to concentrate on their fundamental needs and interests, provide an adaptable process customized to best accommodate parties' circumstances, and foster development of creative resolution); Welsh, The Thinning Vision, supra note 17, at 17-19 (2001) (elucidating core mediation principle of self-determination and importance of active party participation in shaping mediation process and outcome and highlighting mediator's role as "foster[ing] an environment that would 
On the other hand, this process called 'mediation' can also be implemented in a manner that is evaluative, ${ }^{43}$ directive, ${ }^{44}$ and focused on bargaining. ${ }^{45}$ These models present a rather different picture, in which the mediator plays the central role, hopefully beginning by listening to the disputing parties but quickly shifting the focus to the provision of advice to the parties and their lawyers, to help them be realistic regarding their options (usually in civil litigation or administrative adjudication) and to guide them toward a resolution consistent with those options. ${ }^{46}$

The available research suggests that the most effective mediations (and mediators) are likely to combine elements of all of these models. ${ }^{47} \mathrm{~A}$ wealth of research and theory also affirms the importance of providing a mediation process

enable the parties' individual and joint will to emerge").

${ }^{43}$ See L. Randolph Lowry, Evaluative Mediation, in DIVORCE AND FAMILY MEDIATION: MODELS, TECHNIQUES, AND APPILICATIONS 72 (Jay Folberg, et al. eds., 2004); Riskin, Understanding Mediators, supra note 37 , at 4445 (noting although evaluative approach may make it easier for parties to reach resolution because evaluative mediator provides recommendations and assessments, thereby removing some of parties' decision-making burdens, mediators' evaluations may impede parties' ability to appreciate their own and each other's positions and make the process more antagonistic).

${ }^{44}$ See Riskin, Decisionmaking in Mediation, supra note 38, at 30 (defining term directive as "almost any conduct by which the mediator directs the mediation process, or the participants, toward a particular procedure or perspective or outcome").

${ }^{45}$ See Silbey \& Merry, supra note 40, at 19-20 (describing bargaining style mediation as rigid process driven by mediators who "claim authority as professionals with expertise in process, law, and the court system" and blatantly control proceedings, "ignoring emotional demands and concentrating on demands that can be traded off," often preferring caucuses over direct party communication and advising parties of "the benefits of a settlement of any kind").

${ }^{46}$ See Debra Lewis \& Nancy A. Welsh, Adaptations to the Civil Mediation Model: Suggestions from Research into the Approaches to Conflict Resolution Used in the Twin Cities' Cambodian Community, 15 MEDIATION Q. 345, 354 (1998) (revealing preference of sampled ethnic group for mediators who implement evaluative, rather than facilitative methods); Riskin \& Welsh, supra note 42, at 865-66 (discussing "courtoriented" mediation in civil litigation contexts where mediators and other 'repeat players' focus narrowly on likely outcome of litigation and what each party is willing to pay to avoid costs and risks of litigation, and employ mediation procedures most likely to lead to settlement, often excluding consideration of parties' motivations); Nancy A. Welsh, Making Deals in Court-Connected Mediation: What's Justice Got to Do with It?, 79 WASH. U. L. Q. 787, 846 (2001) [hereinafter Welsh, Making Deals] ("Court-connected mediation ... often involves evaluative interventions by the mediator .... [M]ediators regularly provide disputants with 'reality-checks' by critically assessing the strengths and weaknesses of the disputants' cases and even opining regarding appropriate settlement ranges."); Welsh, The Thinning Vision supra note 17, at 4, 47-48 (noting court-institutionalized mediation has departed from previously dominant view, which "assumed that the disputing parties would be the principal actors and creators within the mediation process" and has become a process dominated by mediators who employ evaluative methods, such as persuading parties to accept settlement and assessing strengths and weaknesses of parties' positions, often in private caucuses).

${ }^{47}$ See Riskin, Decisionmaking in Mediation, supra note 38, at 17 (reporting that same mediator was selected as best facilitative mediator and second-best evaluative mediator); Riskin \& Welsh, supra note 42 , at 868-69 (describing positive impact of various mediation theories); Nancy A. Welsh, Stepping Back through the Looking Glass: Real Conversations with Real Disputants About Institutionalized Mediation and Its Value, 19 OHIO ST. J. ON DISP. RESOL. 573, 671 (2004) (suggesting insignificance of "rigid distinctions" among mediation frameworks and positing that "'quality' mediation" demands the use all appropriate methods "that serve procedural justice and resolution rather than development of niches for mediators with different 'orientations'"); see also ABA SECTION OF DISPUTE RESOLUTION, TASK FORCE ON IMPROVING THE QUALITY OF MEDIATION, FINAL REPORT: Apr. 2006-Feb. 2008, at 12-13, 17 (2008) (recommending best practice for mediators is to tailor mediation process to each particular case rather than using the same identical approach and suggesting "techniques sometimes could be used more wisely and prudently"). 
that the parties will perceive as fair ${ }^{48}$-also described as one that offers the parties "an experience of justice." 49 To achieve this experience, the parties need: the opportunity to be fully heard; to know that what they have said has been considered (ideally, by both the mediator and the other party ${ }^{50}$ ); and to feel treated in an evenhanded and respectful manner (again, ideally, by both the mediator and the other party). ${ }^{51}$ All of these procedural characteristics are consistent with the idea of drawing out the parties and affirming their centrality to the dispute and its resolution. Importantly, they also are not inconsistent with a process that involves the mediator ultimately playing a central role in educating and guiding the parties toward resolution. ${ }^{52}$

${ }^{48}$ Nancy A. Welsh, Perceptions of Fairness, in THE NEGOTIATOR'S FIELDBOOK: THE DESK REFERENCE FOR THE EXPERIENCED NEGOTIATOR 165, 171 (Andrea Kupfer-Scheider \& Christopher Honeyman eds., 2007) [hereinafter Welsh, Perceptions of Fairness] (noting research has confirmed link between perceptions of process faimess in negotiation and negotiators' perceptions of faimess of proposed outcomes). In addition to the relationship of the parties to the third-party mediator, the relationship between the parties involved in the mediation and the negotiators themselves is also important. Negotiators' relative status in the group helps to determine the impact of procedural fairness on their attitudes and behaviors. In a negotiation between two individuals that perceive themselves to be of uneven status, the lower status negotiator will likely be more satisfied with the outcome if she perceives she has been treated in a procedurally just manner by the higher status negotiator. On the other hand, the higher status negotiator will perceive the process to be fair only if there is a favorable outcome. Id. at 171; Welsh, Making Deals, supra note 46, at 818 ("Disputants who believe that they have been treated in a procedurally fair manner are more likely to conclude that the resulting outcome is substantively fair."). Researchers have found that procedural justice matters. Disputants' perceptions of the justice provided by a procedure affect their judgments of the distributive justice provided by the outcome, their compliance with that outcome, and their faith in the legitimacy of the institution that offered the procedure. Disputants use the following indicia to assess procedural justice: whether the procedure provided them with the opportunity to tell their stories; whether the third party considered their stories; and whether the third party treated them in an even-handed and dignified manner. Id. at 817; see Yuval Feldman \& Tom Tyler, Mandated Justice: The Potential Promise and Possible Pitfalls of Mandating Procedural Justice in the Workplace 25-26 (Sept. 7, 2009) (unpublished manuscript, available at http://ssm.com/abstract=1133521) (examining concept of procedural justice in company management decisions and concluding employees' behavior is positively impacted when they view their employers' methods for promotional and pay increase evaluations as fair).

${ }^{49}$ See Welsh, Making Deals, supra note 46, at 791-92 (describing expectation disputants have regarding mediation process and its affect on their perception and compliance with outcome of dispute resolution process).

${ }^{50}$ See Lisa Bingham \& Tina Nabatchi, Address at the International Conflict Management Association 2006 Conference: The Determinants of Outcomes in Transformative Mediation (June 27, 2006) (discussing importance of being heard by other disputant).

${ }^{51}$ Donna Shestowsky, Disputants' Preferences for Court-Connected Dispute Resolution Procedures: Why We Should Care and Why We Know So Little, 23 OHIO ST. J. ON DISP. RESOL. 549, 575 (2008) (noting people will still be satisfied with unfavorable results if they perceived the process to be a fair); see FRIEDMAN \& HIMMELSTEIN, supra note 39; TAMARA RELIS, PERCEPTIONS IN LITIGATION AND MEDIATION: LAWYERS, DEFENDANTS, PlaINTIFFS, AND GENDERED PARTIES 174 (2009) (positing disputants feel they have been treated justly and fairly when mediators give due consideration to their perspectives); Welsh, Perceptions of Fairness, supra note 48, at 170 ("[P] eople who believe that they have been treated in a procedurally fair manner are more likely to conclude that the resulting outcome is substantively fair, even if that outcome is unfavorable."); Welsh, Making Deals, supra note 46, at 823-24 (noting fair treatment will lead disputant to feel procedural justice was served regardless of unfavorable outcome); Welsh, Stepping Back, supra note 47, at 623 (indicating perception of mediation process enhances dignity of manner in which parties conduct themselves).

${ }^{52}$ See Welsh, Making Deals, supra note 46, at 805-06 (positing attorneys prefer mediators who play more 
So which model of mediation is best? Which model should be institutionalized in the courts, particularly courts with mandatory mediation programs? Battles have been fought over these questions ${ }^{53}$ and research has been done, ${ }^{54}$ fueled at least in part by the hunger for legitimacy and access to the remunerative ${ }^{55}$ business of mediation.

The answers to these questions depend, of course, on the goals of the mediation process. If the aim of mediation is to enhance the parties' ability to communicate and negotiate directly with each other-which may be particularly important when there will be an ongoing relationship ${ }^{56}$ and a need to collaborate in the implementation of any agreement-it appears important for the process to foster parties' ability to engage in "mutual consideration." ${ }^{57}$ In other words, the parties

active role by commenting on parties' argument strength and outlining settlement ranges); Welsh, Stepping Back, supra note 47, at 576 (identifying "transformative" interventions as process of "enhancing disputants' communication and mutual understanding to enable the disputants to find their own way to a settlement" through their own empowerment).

${ }_{53}$ Welsh, The Thinning Vision, supra note 17, at 27-29 (citing to many articles written about debates over superiority of facilitative, evaluative and transformative mediation); Welsh, Stepping Back, supra note 47, at 576 (noting continuing debate exists regarding level of involvement mediators should have in mediation process).

54 Tina Nabatchi et al., Evaluating Transformative Mediation in Practice: The Premises, Principles, and Behaviors of USPS Mediators 1 (July 13, 2006) (unpublished manuscript, available at $\mathrm{http}: / / \mathrm{ssrn} . \mathrm{com} /$ abstract $=916008$ ) (evaluating transformative mediation program used by Unites States Postal Service.); see Shestowsky, supra note 51, at 572 (2008) (positing method should be adopted that aligns with disputants' mediation preferences) (citing Roselle Wissler, The Effects of Mandatory Mediation: Empirical Research on the Experience of Small Claims and Common Pleas Courts, 33 WILLAMETTE L. REV. 565, 570 (1997) [hereinafter Wissler, Effects of Mandatory Mediation]); see also Dorothy J. Della Noce et al., Signposts and Crossroads: A Model For Live Action Mediator Assessment, 23 OHIO ST. J. ON DISP. RESOL. 197, 206-07 (2008) (discussing transformative mediation as function of mediator's understanding of her supporting role in parties' efforts to resolve conflict); Welsh, Stepping Back, supra note 47 , at 580 (evaluating various models in context of school education mediation and relating it to broader field of mediation).

${ }_{55}$ The level of remuneration, however, can vary dramatically. See Andrew K. Niebler, Getting the Most Out of Mediation: Toward a Theory of Optimal Compensation for Mediators, 4 HARV. NEGOT. L. REV. 167, 172-73 (1999) (explaining amount of mediator compensation depends on whether mediator is paid on uniform hourly fee or variable hourly fee and duration of mediation).

${ }^{56}$ See McAdoo \& Welsh, supra note 25, at 403 (discussing Frank Sander's description of Lon Fuller's articulation of central quality of mediation identified as maintenance of long-term relationships through solution worked out by parties); see also ROSEMARY O'LEARY \& LISA B. BINGHAM, A MANAGER'S GUIDE TO RESOLVING CONFLICTS IN COLLABORATIVE NETWORKS 25 (2007) (identifying positive effects resulting from managers' awareness of need to listen). But see Dwight Golann, Is Legal Mediation a Process of Repair - or Separation? An Empirical Study and Its Implications, 7 HARV. NEGOT. L. REV. 301, 331 (2002) ("Even when able mediators work with parties whose dispute arises in the context of a significant prior connection with each other, relationship repairs in legal mediation appear to be uncommon events . . . ."); Bobbi McAdoo, A Report to the Minnesota Supreme Court: The Impact of Rule 114 on Civil Litigation Practice in Minnesota, 25 HAMLINE L. REV. 403, 429 (2002) (noting minority of lawyers voluntarily chose mediation because of its ability to preserve parties' relationship); Roselle Wissler, The Effectiveness of CourtConnected Dispute Resolution in Civil Cases, 22 CONFLICT RESOL. Q. 55, 67 (2004) (highest percentage from various studies stated that $43 \%$ of litigants thought mediation improved relationships with other party; most studies did not support this).

${ }^{57}$ See Welsh, Stepping Back, supra note 47, at 639 (describing term there as "reciprocal voice and understanding" and with thanks to Bobbi McAdoo for suggesting term). 
need the opportunity to speak and be heard, but they also need the opportunity to listen to each other, reflect upon what was said and demonstrate that they have listened to each other. ${ }^{58}$

For a variety of reasons, the achievement of mutual consideration can be a significant challenge. At least some percentage of disputing parties-perhaps those who are less polarized, afraid or stressed; inherently creative; reasonably assertive and confident; able to achieve some distance from their dispute - will be able to engage in the elicitive, facilitative, and transformative process described supra and ultimately craft their own resolution, one that they will implement through good times and bad. ${ }^{59}$ The needs of these parties-provided there is also some surplus to divide in their bargaining zone and/or the opportunity for logrolling or the creation of new, integrative options-will be fully met by a mediation in which the mediator limits herself to the use of facilitative, elicitive and perhaps transformative interventions.

Parties who do not quite match this profile may be lucky enough to be assisted by lawyers who possess the creativity, assertiveness, empathy, rationality and detachment that their clients lack. These lawyers also may fully understand, respect and be able to communicate the needs of their clients. ${ }^{60}$ Furthermore, these lawyers may possess a full complement of the more traditional abilities of the lawyersufficient substantive knowledge to provide competent representation, along with the ability to analyze, speak and write "like a lawyer." ${ }^{16}$ Parties represented by these lawyers may also find their needs sufficiently met by a facilitative, elicitive and/or transformative model of mediation. ${ }^{62}$

But for those parties who cannot achieve a sufficiently-positive problemsolving state-or when their lawyers do not possess the skills and knowledge

\footnotetext{
${ }^{58}$ See id. at 639 (noting positive and negative reactions to real mediation between parents and school officials); see also Shestowsky, supra note 51, at 567 (noting main ADR goal gives individuals selfdetermination over mediation).

59 See Pruitt et al., Social Conflict: Escalation, Stalemate and Settlement (3d ed. 2004) (describing evolution of conflict).

${ }^{60}$ See Julie Macfarlane, The New Lawyer: How SetTlement Is Transforming the Practice of LAW 23 (UBC Press 2008) (arguing "the new lawyer" must have evolved beliefs and practices).

${ }^{61}$ Within the past couple of years, there have been increasing calls for law schools to prepare law students for the sort of skillful and ethical use of substantive legal knowledge that is suggested here. See RoY StUCKey, et Al., Best Practices in Legal EduCATION: A Vision AND a RoAd MAP 8 (2007) (outlining goals for law school classes); William M. SUlLIVAN, ET AL., EDUCATING LAWYERS: PrEPARATION FOR THE PROFESSION OF LAW 17 (2007) (analyzing law school teaching methods); see also MACFARLANE, supra note 60, at 23 (discussing what distinguishes new lawyering from old lawyering); John Lande \& Jean Sternlight, The Potential Contribution of ADR to an Integrated Curriculum: Preparing Law Students for Real World Lawyering, 25 OHIO ST. J. OF DISP. RESOL. (forthcoming 2010). Interestingly, as long ago as 1997, two faculty members at the Dickinson School of Law of Penn State University prepared and taught a course that specifically integrated bankruptcy law and mediation skills. Peter C. Alexander et al., Integrating Alternative Dispute Resolution into the Bankruptcy Curriculum, 102 DICK L. REV. 259, 260 (1998) (noting class goal in creating one form of bankruptcy resolution).

${ }^{62} \mathrm{I}$ do, however, have concerns about the likelihood of such parties begin able to work through the inevitable problems that will arise in the implementation of an agreement that requires an ongoing relationship. See Peter Kamminga, (Aug. 15, 2009) (unpublished Ph.D. dissertation, Tilburg University) (on file with author) (regarding use of consensual processes in construction industry).
} 
described supra or do not have an ideal relationship with their clients, or when there is no surplus to divide-the more appropriate mediation process may be one in which the mediator first listens with an open mind and in a manner that conveys respect and then moves toward dignified, participatory education of the parties about their options, advises them about the fairness of these options, and helps them to make an appropriate choice. These procedural characteristics, of course, are consistent with a model of mediation that begins in a facilitative manner then, if necessary, begins to include evaluative or directive elements. I hasten to add, however, that these characteristics are not consistent with coercive or muscle mediation.

Research suggests that institutional and financial pressures have forced courtconnected mediation (and mediators) to become predominantly evaluative, directive-and even coercive. Many have laid the blame for this transformation at lawyers' doors, ${ }^{63}$ observing that lawyers' participation has made the mediation process more adversarial and single-mindedly focused on the law and legal procedures. There is much to support this assessment. Lawyers tend to select other lawyers as mediators, dominate the discussions in the mediation process, seek case valuation and reality-testing, and focus on brokering a deal. ${ }^{64}$ The achievement of mutual understanding between the parties seems to be an issue that some lawyers think about ${ }^{65}$ but not many. ${ }^{66}$

${ }^{63}$ See Kimberlee K. Kovach, Good Faith In Mediation - Requested, Recommended or Required? A New Ethic, 38 S. TEX. L. REV. 575, 593 (1997) (The increase of court-connected mediation and the incorporation of lawyers into the process have stripped mediation of its benefits as an altemative to the adversarial system and is in danger of becoming another "hoop" on the path to litigation. "The notion of mediation as a different paradigm for dispute resolution is being eroded with the lawyers now viewing the process as merely another tool within the litigation arena to be used combatively rather for any intended purpose."); Leonard L Riskin, The Represented Client in A Settlement Conference: The Lessons of G. Heileman Brewing Co. v. Joseph Oat Corp., 69 WASH. U. L.Q. 1059, 1081 (1991) (arguing lawyers adversarial nature narrows settlement visions); Riskin \& Welsh, supra note 42, at 867 (positing courts, not lawyers, should present mediation opportunities); Welsh, Making Deals, supra note 46, at 797-98 (noting lawyers make mediation look like judicial settlement conferences).

${ }^{64}$ See Tamara Relis, Consequences of Power, 12 HARV. NEGOT. L. REV. 445, 446 (2007) (arguing "that due to disparities in knowledge, power, and interests between litigants and attorneys, plaintiffs and defendants are regularly not afforded communication opportunities to address issues of prime importance to them during the processing of their cases"); Riskin \& Welsh, supra note 42, at 893 (describing existing current empirical research on this point); Roselle Wissler, Court-Connected Arbitration in the Superior Court of Arizona: A Study of its Performance and Proposed Rule Changes, 2007 J. DISP. RESOL. 65, 90-91 (2007) (arguing lawyers favor judicializing the process by having the courts provide some-type of compulsory alternative process); Welsh, The Thinning Vision, supra note 17, at 26 (comparing lawyer involved mediations with judicial settlement conferences); see also Welsh, Making Deals, supra note 46, at 797 (claiming some believe lawyers "hijacked" mediation process).

${ }_{65}$ See MACFARLANE, supra note 60, at 149-50 (describing collaborative law and value of client participation and discussion between parties); John Lande, Principles for Policymaking About Collaborative Law and other ADR Processes, 22 OHIO ST. J. ON DISP. RESOL. 619, 626-28 (2007) (providing background of collaborative law); Nancy A. Welsh, Looking Down the Road Less Traveled: Challenges to Persuading the Legal Profession to Define Problems Humanistically, 2008 J. DiSP. RESOL. 45, 58-59 (2008) [hereinafter Welsh, Looking Down the Road] (discussing lawyers who practice mediation and understanding of parties' interest); see also McAdoo, supra note 13, at 398-99 tbl.8 (2007) (observing among top reasons judges order cases to mediation is because they believe process "gets clients directly involved in discussions"). 
It is also important to note, however, that this transformation may have something to do with the courts themselves-and particularly with the courts' relative lack of resources and focus on "speedy" and "inexpensive"67 disposition. Some courts now assume that a mediation will be completed in an hour. Courts have long tracked the rate at which mediation successfully settles cases and have regularly noted mediation's value as a means to reduce the size of the court's docket. ${ }^{68}$ None of these preferences or behaviors is inherently evil. Instead, as courts deal constantly with cost-conscious administrators, intrusive legislators, and unhappy citizens who arrive with difficult problems that require timely resolution, courts are acting in a manner consistent with institutional self-preservation. ${ }^{69}$

And there is one other factor that must be considered-the parties themselves. Very few people go directly to court after they have been harmed. Most peopleeven allegedly litigious Americans-prefer not to go to court. ${ }^{70}$ Plaintiffs must proceed through a multi-stage psychological process-naming, blaming, and claiming ${ }^{71}$ - before they sue defendants. Usually, at least one of the parties involved in this lawsuit has tried to negotiate with the other-and has been unsuccessful. ${ }^{72}$ In the United States, research shows that only a small percentage of

\footnotetext{
${ }^{66}$ See Relis, supra note 64, at 463-64 (noting female and/or in-house hospital lawyers were more likely to raise this possibility); Riskin \& Welsh, supra note 42, at 869-73 (discussing goal of mediation is to attend to parties' needs but evidence shows this is rarity); Welsh, Looking Down the Road, supra note 65, at 50-51 (hypothesizing about why so many lawyers find it so difficult to deal with emotional issues and how those issues may benefit from acknowledgment in legal practice). Meanwhile, judges referring parties to mediation do seem impressed with this potential benefit of the process. See McAdoo, supra note 13, at 398-99 (stating judicial preference for discussion between parties as result of mediation).

${ }^{67}$ See FED. R. CIV. P. 1. (stating every action should be just, speedy and inexpensive).

${ }^{68}$ See McAdoo \& Welsh, supra note 25, at 406 (explaining modern realization that ADR is cost and time efficient); Moffitt, supra note 5; Nancy A. Welsh, The Place of Court-Connected Mediation in a Democratic Justice System, 5 CARDOZo J. CONFLICT RESOL. 117, 129-30 (2004) [hereinafter Welsh, Court-Connected Mediation] (documenting trend in judicial deferral to arbitration due to efficiency and lower cost).

${ }^{69}$ See Judith Resnik, Trial as Error, Jurisdiction as Injury: Transforming the Meaning of Article III, 113 HARV. L. REV. 924, 936-37 (2000) (describing evolution of ADR as method of controlling judicial case overload, and its evolution from pre-trial); see also Judith Resnik, "Uncle Sam Modernizes his Justice": Inventing the Federal District Courts of the Twentieth Century for the District of Columbia and the Nation, 90 GEO. L.J. 607, 649 (2002) (discussing judicial welcome to alternative dispute resolution to ease caseload); Welsh, Court-Connected Mediation, supra note 68, at 141 (discussing mediator's role in keeping people happy and delivering justice).

${ }^{70}$ See Marc Galanter, Reading the Landscape of Disputes: What We Know and Don't Know (And Think We Know) About Our Allegedly Contentious and Litigious Society, 31 UCLA L. REv. 4, 22 (1983) [hereinafter Galanter, Reading the Landscapes of Disputes] (detailing study result finding only approximately $5 \%$ of inter-organizational disputes went to trial) (citing Hurst, The Functions of Courts in the United States, 19501980, 15 LAW \& SOC'Y REV. 401, 422 (1980) ("The absence of sizeable numbers of legal actions in which individuals or firms of substantial or large means appear on both sides of lawsuits.")).

${ }^{71}$ See William L. F. Felstiner et al., The Emergence and Transformation of Disputes: Naming, Blaming, Claiming . . . 15 LAW \& SOC'Y REV. 631, 635-36 (1980) (explaining three-step process before trial of naming injury, blaming other party, and claiming grievance by voicing to third party and instigating trial). Note that the "claiming" part also can be quite expensive, beyond many people's means. See id. at 636-37 (stating costs to parties may limit access to justice and ability to bring claims).

72 See Richard E. Miller \& Austin Sarat, Grievances, Claims and Disputes: Assessing the Adversary Culture, 15 LAW \& SOC'Y REV. 525, 537 tbl.2 (1980) (showing 32\% of all grievances come to no agreement following negotiation and $30.6 \%$ reach agreement after difficulty).
} 
those who perceive that they have suffered a harm end up bringing a lawsuit. ${ }^{73}$ It should not be surprising, then, that many of these disputing parties who have finally reached the courthouse find it hard to believe that a reasonably fair resolution with the other party is possible. ${ }^{74}$ Many-though certainly not all ${ }^{75}$ - have given up any hope for a voluntary, jointly-developed resolution and now prefer to trust the judgment of a stranger, someone they hope will not only be impartial but benevolent, knowledgeable, and fair. ${ }^{76}$ Indeed, research has shown that parties are more likely to perceive a mediation process as fair if the mediator listens but also engages at some point in an evaluative or directive intervention-e.g., if she helps parties to assess the strengths and weaknesses of their cases. ${ }^{77}$ I have suggested elsewhere that the parties may turn to mediators in this manner because they seek reassurance that the resolution they are considering is reasonably fair. ${ }^{78}$ Significantly, though, parties are much less receptive to mediators who go further and try to tell the parties what to do-i.e., recommend specific settlements. ${ }^{79}$ In

${ }^{73}$ Galanter, Reading the Landscapes of Disputes, supra note 70 , at 20 (The Civil Litigation Research Project found that only $5 \%$ median and $17 \%$ mean of organizational disputes actually go to court. The Milwaukee Consumer Dispute Study found that of the people that reported problems, only $3 \%$ took claims to third party, and another study by Best and Andreasen found that only $3.5 \%$ of those consumers that voiced complaints involved third parties); Marc Galanter, A World Without Trial?, 2006 J. DISP. RESOL. 7, 9-10 (2006) (The National Center for State Courts, where $98 \%$ of the trials occur, complied a bank of state trial data between 1976 and 2002 and reported that the courts of general jurisdiction in 22 states reported declines in the amount of dispositions from $1.8 \%$ in 1976 to $0.6 \%$ in 2002 , as well as a reduction of overall criminal trials from $8.5 \%$ in 1976 to $3.3 \%$ in 2002 . This trend is the same in federal courts.); Marc Galanter, The Vanishing Trial: An Examination of Trials and Related Matters in Federal and State Courts, 1 J. OF EMPIRICAL LEGAL STUD. 459, 459, 498 (2004) (noting portion of federal civil cases resolved by trial fell from $11.5 \%$ in 1962 to $1.8 \%$ in 2002 . There was also a similar $60 \%$ decline in the absolute number of trials since the mid 1980s. Trials are declining in every case category. A similar decline in both the percentage and the absolute number of trials is found in federal criminal cases and in bankruptcy cases. In 1985, there were 9.287 trials in bankruptcy court; by 2002, there were 3.179 - little more than one third of 1985 total).

${ }^{74}$ Sally Engle Merry \& Susan S. Silbey, What Do Plaintiffs Want? Reexamining the Concept of Dispute, 9 JUST. SYS. J. 151, 153 (1984) (noting by the time conflict comes to court it is serious enough that plaintiff wants outside intervention because they do not want to take dispute back into their own hands).

${ }^{75}$ See Relis, supra note 64, at 478-79 (describing patients and doctors who wanted to talk with each other in medical malpractice mediations); see also Hensler, supra note 17, at 189 (claiming facilitative mediator, unlike evaluative mediator, would be more helpful in finding joint gains and allowing parties to come to own settlements as opposed to proposing resolution).

${ }^{76}$ Compare Donna Shestowsky \& Jeanne Brett, Disputants' Perception of Dispute Resolution Procedures: An Ex Ante and Ex Post Longitudinal Empirical Study, 41 CONN. L. REV. 63 (2008) (finding empirical data showed parties are more attracted initially to third-party control were satisfied when they experienced adjudication), with Wissler, Effects of Mandatory Mediation, supra note 54, at 584-85 (discovering mixed effects on evaluations of mediation process from parties who were required to mediate as opposed to those who voluntarily mediate).

77 See Roselle L. Wissler, Court-Connected Mediation in General Civil Cases: What We Know From Empirical Research, 17 OHIO ST. J. ON DISP. RESOL. 641, 664, 698 (2002) [hereinafter Wissler, General Civil Cases] (explaining $49 \%$ of parties thought mediation gave them better understanding of strengths and weaknesses and arguing parties in mediation felt mediation process was more fair when they were better prepared).

${ }^{78}$ McAdoo \& Welsh, supra note 25, at 425 (claiming mediators produce fair outcomes especially when they provide reassurance that outcomes are consistent with rule of law).

${ }^{76}$ See Wissler, General Civil Cases, supra note 77, at 684-85 (showing party felt more pressure to accept settlement from mediator who recommended particular settlement, while attorney felt mediation was more 
particular, non-settling parties perceive the process as less fair when mediators engage in this intervention.

All of this research suggests that most, though not all, parties want advice from someone they have decided they can trust. Other research, meanwhile, suggests that lawyers and other repeat players prefer an actual decision-provided that it is reached efficiently, consistent with the law and their expectations, and very likely to be complied with or enforced. They seem to care less than the average person-a one-shot player ${ }^{80}$-about procedural justice. Indeed, some research suggests that lawyers' and repeat players' positive perceptions regarding the process will be much less likely to influence their assessments of the fairness or unfairness of the outcome. $^{81}$

All of these factors may combine to explain the current directive or evaluative cast of much court-connected mediation, which exists in order to assist the mass processing of cases and is dominated by repeat players. ${ }^{82}$ Further, the factors described supra certainly can tempt mediators and court-connected mediation programs to use, or acquiesce in the use of, coercive or muscle mediation in order to achieve settlements. ${ }^{83}$

\section{INTRODUCTION OF MEDIATION INTO BANKRUPTCY COURTS}

Mediation was first integrated into bankruptcy courts when the Bankruptcy Court for the Southern District of California established a mediation program in $1986 .^{84}$ Courts in other parts of the country soon followed suit. ${ }^{85}$ After passage of the Civil Justice Reform Act of 1990, bankruptcy judges began experimenting with ADR, including mediation, on an ad hoc basis. ${ }^{86}$ That same year, under the auspices

fair after mediator had suggested possible settlement option); see also Riskin \& Welsh, supra note 42, at 874 ("Most Lawyers ... prefer that retired judges or experienced litigators with relevant substantive expertise serve as their mediators.").

80 See Marc Galanter \& Mia Cahill, "Most Cases Settle": Judicial Promotion and Regulation of Settlements, 46 STAN. L. REV. 1339, 1353 (1994) (describing one shot players as individuals who file lawsuits, settle claim instead of litigating, and are unhappy with settlement outcome).

${ }^{81}$ See Welsh, Perceptions of Fairness in Negotiation, supra note 48, at 170-71 (describing recent research); see also JANE ADLER ET AL., SIMPLE JUSTICE: HOW LITIGANTS FARE IN THE PITTSBURGH COURT ARBITRATION PROGRAM 61-62 (1983) (discussing difference between organizational and individual parties' reactions to Pittsburgh arbitration program).

${ }^{82}$ See Riskin \& Welsh, supra note 42, at 865-66 (stating "court-oriented" mediations allow "repeat players" to settle more issues without interference).

${ }_{83}$ I must admit that when I think of the contrast between educating or coaching parties in evaluative/directive mediation vs. browbeating or berating parties in coercive/muscle mediation, I recall a recent episode of the Penguins of Madagascar in which the lead penguin announces, "I find reason tedious and boring. We'll use force." The Penguins of Madagascar: Gone in a Flash (Nickelodeon television broadcast November 28, 2008). Since this television show is a comedy, I believe that the penguins' use of force fails to achieve its intended result. In real life, of course, that is not always the case.

${ }^{84}$ See Cassandra G. Mott, Note, Macy's Miracle on 34th Street: Employing Mediation to Develop the Reorganization Plan in a Mega-Chapter 11 Case, 14 OHIO ST. J. ON DISP. RESOL. 193, 198 (1998).

${ }_{85}$ See id. at 199 (stating Bankruptcy courts in Middle District of Florida and Eastern District of Virginia imitated Southern District of California).

${ }^{86}$ See id. at 196 (discussing how judges experimented with different forms of alternative dispute 
of the American Arbitration Association, bankrupt Greyhound Lines Inc. offered the first pre-reorganization plan mediation to thousands of individuals who had brought personal injury and property damage claims against the company, as a result of traffic accidents involving Greyhound vehicles. ${ }^{87}$ In late 1993, the Bankruptcy Court for the influential Southern District of New York created its court-connected mediation program. ${ }^{88}$ One of the first referrals to the program involved the chapter 11 reorganization of $\mathrm{R} . \mathrm{H}$. Macy \& $\mathrm{Co}^{89}$ The mediator in that case was Cyrus Vance, and the mediation process, which lasted two weeks, was "called Camp Mediation by the creditors' army of lawyers and bankers." ${ }^{90}$ By 1995, twelve bankruptcy courts had adopted court-connected ADR programs. ${ }^{91}$ Then, with the passage of the Alternative Dispute Resolution Act of 1998, federal bankruptcy courts received express authorization to use ADR processes, including mediation. ${ }^{92}$ By 2004, the Bankruptcy Court for the District of Delaware was requiring that before parties could proceed with certain adversary proceedings, they had to attempt to reach resolution through mediation. ${ }^{93}$

Today, as a result of the work of Professor Ralph Peeples, we know that 40 bankruptcy courts have rules or standing orders that permit mediation. ${ }^{94}$ Professor William Woodward has revealed that, in addition to interesting experimentation with mediation in preference cases and bankruptcy appeals, a bankruptcy procedure spawned both the Piper Trust and a claims process that requires use of mediation. ${ }^{95}$ Our unfortunately-difficult current economic conditions, combined with the successful use of mediation in this and other contexts, make it very likely that the use of mediation in bankruptcy will expand. ${ }^{96}$

resolution).

87 See Penna, supra note 2 (discussing program set up by banknupt Greyhound Lines Inc to deal with personal injury and property claims).

${ }^{88}$ See Mott, supra note 84, at 199 (acknowledging Judge Lifland for helping bring about a court-annexed mediation program in the Bankruptcy Court for the Southern District of New York).

${ }^{89}$ See id. at 194 (noting use of mediation in Macy's chapter 11 case).

90 Stephanie Strom, Macy's Biggest Sale - A Special Report: Derailing a Big Bankruptcy Plan, N.Y. TIMES, July 29, 1994, at D1.

91 Ralph R. Mabey, et al., Expanding the Reach of Alternative Dispute Resolution in Bankruptcy: The Legal and Practical Bases for the Use of Mediation and the Other Forms of ADR, 46 S.C. L. REV. 1259, 1266 (1995) (establishing adoption of twelve "court-annexed ADR programs" in bankruptcy courts); Mott, supra note 84, at 199 ("[T]welve bankruptcy courts have court-annexed ADR programs.").

92 See 28 U.S.C. $\$ 651$ (b) (1998) ("Each United States district court shall authorize, by local rule adopted under section 2071(a), the use of alternative dispute resolution processes in all civil actions, including adversary proceedings in bankruptcy ....").

${ }^{93}$ See Mark L. Desgrosseilliers, Gimme Shelter: The Use of Alternative Dispute Resolution Procedures to Resolve Tort Claims in Bankruptcy, 18 NORTON J. BANKR. L. \& PRAC. 19, 32 (2009) (demonstrating Delaware Bankruptcy Court's mandate of mediation prior to certain proceedings).

${ }^{94}$ See Ralph Peeples, The Uses of Mediation in Chapter 11 Cases, 17 AM. BANKR. INST. L. REV. 401, 407 (2009) ("Mediation is explicitly authorized by local rule or order in 51 bankruptcy courts.").

${ }_{95}$ See generally Woodward, supra note 1.

${ }^{96}$ See Desgrosseilliers, supra note 93, at 43 (2009) (suggesting ADR procedures are viable options to manage heavy load of bankruptcy litigation in future); Abigail Johnson, Mediation growing in bankruptcy courts; Mediators help avoid costs of litigation, IND. LAW., April 19, 2006, at 6 ("At this point in his career, Kleiman said mediation duties take up about 15 percent to 20 percent of his time. And, while mediation in 


\section{What ReCENT BANKRUPTCy CASES SugGest About COURTS' AND PARTIES' UNDERSTANDING OF MEDIATION AND MEDIATORS}

As noted supra, relatively few judicial opinions discuss the use of mediation in bankruptcy. There are several obvious reasons for this. First, bankruptcy courts have only recently begun to use mediation. ${ }^{97}$ Second, because mediation is confidential, can be initiated privately, ${ }^{98}$ and requires the parties' agreement in order to produce an outcome, bankruptcy judges ${ }^{99}$ are relatively unlikely to be called upon to resolve issues involving mediation. ${ }^{100}$ The few cases available nonetheless demonstrate that bankruptcy courts generally favor the use of mediation to resolve claims and help with reorganizations. One case, which is a bit of an anomaly, ${ }^{101}$ represents a cautionary tale in which creative parties attempted to use mediation as a convenient, unregulated tool that would permit them to achieve unexpected and inappropriate results. ${ }^{102} \mathrm{~A}$ bankruptcy judge, who balked at using mediation in this manner, stopped these parties. ${ }^{103}$ Some other bankruptcy judges and parties, however, apparently expect mediators to do more than facilitate communication,

the bankruptcy court is becoming more common, Kleiman definitely sees it as a growth area." David Kleiman was the first mediator to handle a case for the bankruptcy court in Indianapolis in the late 1990s.).

${ }_{97}$ See James R. Coben \& Peter N. Thompson, Disputing Irony: A Systematic Look at Litigation About Mediation, 11 HARV. NEGOT. L. REV. 43, 52-53 (2006) [hereinafter Coben \& Thompson, Disputing Irony] (describing likely reasons for relatively recent development of bankruptcy mediation jurisprudence); James R. Coben \& Peter N. Thompson, Mediation Litigation Trends: 1999-2007, 1 WORLD ARBITRATION \& MEDIATION REV. 395, 414 (2007) (explaining recent trends in mediation).

${ }_{98}$ There may be some limitations on the ability to contract for private mediation in the bankruptcy context due to the requirement in 11 U.S.C. $\S 363$ that the Debtor to receive court approval for payments made outside of the ordinary course. Mediation costs may be included within that scope. 11 U.S.C $\S 363($ b) (1) (2006). My thanks to Margaret Whiteman Greecher for this observation.

${ }_{99}$ See Jeffrey J. Rachlinski et al., Inside the Bankruptcy Judge's Mind, 86 B.U. L. REV. 1227, 1230 (2006) (exploring whether specialization of bankruptcy judges enables superior decision making).

${ }^{100}$ See Coben \& Thompson, Disputing Irony, supra note 97, at 52-53 (describing related reasons for relative paucity of mediation jurisprudence).

${ }^{101}$ Or the egregious tip of the iceberg. See Maureen A. Weston, Checks on Participant Conduct in Compulsory ADR: Reconciling the Tension in the Need for Good-Faith Participation, Autonomy, and Confidentiality, 76 IND. L.J. 591, 596 (2001) (remarking on abuses of process within ADR system). My thanks to Chris Honeyman for noting this possibility.

${ }^{102}$ See In re Am. Capital Equip., 405 B.R. 415, 422 (Bankr. W.D. Pa. 2009) (remarking on attempt by party to abuse mediation process). Reminiscent of the creative financiers whose new investment vehicles helped to create our current economic crisis. See Joseph Philip Forte, Disruption in the Capital Markets: What Happened? 22 A.B.A. SEC. PUB. REAL PROP. TR. \& EST. L. 8, 11 (2008) (discussing various loan products utilized during real estate boom). However, lawyers seeking to use mediation in seemingly inappropriate ways might not be purposing these methods out of malice or to gain an unfair advantage but rather to pursue an altruistic means, such as expediating recovery for entitled and needy tort claimants. For example, see generally Penna, supra note 2 (reporting that Thomas Lauria, attorney for Greyhound, explained his client had intiated ADR in part to "balance bankruptcy policies which require efficient estate adminstration, on the one hand, and [responding to] the interests of personal injury and property damage claimants, on the one hand, who need and indeed are entitled to quick payments of their claims-without having to get involved in the ordinary complexity and delays associated with large corporate bankruptcy.").

${ }^{103}$ See In re Am. Capital Equip., 405 B.R. at 423 (stating bad faith in process reason for not confirming plan). 
negotiation, and resolution. They expect mediators to make decisions and then grant substantial deference to those decisions. Admittedly, mediation is relatively ill-defined. Nonetheless, these judges and parties clearly do not understand even the existing, relatively minimal boundaries that define mediation and mediators.

One of the most significant uses of mediation in the bankruptcy context is the inclusion of the process in chapter 11 reorganization plans, in order to resolve claims that do not come within the limited jurisdiction of bankruptcy procedures. Courts appear to favor the process in this context, provided that it is being used in a manner that treats all interested parties appropriately-or at least not inappropriately. For example, in In re Eagle Bus Manufacturing, ${ }^{104}$ the United States Bankruptcy Court for the Southern District of Texas approved a prereorganization plan involving three-tiered ADR (i.e., offer and exchange; followed by 60 days of mediation; then binding arbitration). ${ }^{105}$ In particular, the court approved the plan's use of these ADR procedures to resolve unsecured creditors' claims of personal injury, wrongful death claims and workers compensation. ${ }^{106}$ In all three types of claims, liability was contested but could not be resolved in the bankruptcy court. ${ }^{107}$ In approving the ADR plan in this case, the court affirmed ADR's ability to bridge the jurisdictional difficulties created by parallel proceedings in trial and bankruptcy courts and to bridge the standing issues created by bankruptcy's hierarchy of creditors. Specifically, the ADR plan permitted unsecured creditors to reach resolution of their non-bankruptcy claims outside the context of the bankruptcy action.

In contrast, in 2009, the U.S. Bankruptcy Court for the Western District of Pennsylvania denied a fifth ${ }^{108}$ reorganization plan proposed by Skinner Engine Company, based on the court's conclusion that the ADR plan was neither reasonable nor entered into in good faith. ${ }^{109}$ Somewhat like the plan in In re Eagle Bus Manufacturing, Skinner's plan provided for mediation of personal injury, asbestosrelated claims that had been brought against the debtor. ${ }^{110}$ But Skinner's plan also required the personal injury claimants to pay to Skinner twenty-percent of the money they received from Skinner's insurers as a result of the mediation. ${ }^{111}$ According to the Bankruptcy Court, Skinner planned to use these proceeds to fund its ADR plan and obtain a recovery for its general creditors. ${ }^{12}$ Skinner thus had an interest in assisting claimants and "abotage[ing] its own defense or, more aptly, the

\footnotetext{
104134 B.R. 584 (Bankr. S.D. Tex. 1991). Discussed in journal articles as the "Greyhound bankruptcy or reorganization plan."

${ }^{105}$ See id. at 586, 591 (confirming reorganization plan including three-step ADR); Penna, supra note 2, at 3 (describing three-tiered ADR process).

${ }_{106}^{06}$ See In re Eagle Bus Mfg., 134 B.R. at 591.

${ }_{107}^{107}$ See id. (noting Bankruptcy Court may not have jurisdiction to hear these particular claims).

${ }^{108}$ According to the court's opinion, this represented at least the fifth chapter 11 plan proposed "within a span of some five to six years." In re Am. Capital Equip., 405 B.R. at 427.

${ }_{109} \mathrm{ld}$. at 422 .

${ }^{110} \mathrm{Id}$. at 418,422 .

111 Id. at 422 .

${ }^{112}$ Id. at $427 \&$ n.7.
} 
Insurers' defense" of Skinner. ${ }^{113}$ Not surprisingly, and particularly because they had never made any payments on these claims, some of which had existed for 20 years, ${ }^{114}$ Skinner's insurers objected to this scheme. ${ }^{115}$ The court labeled the ADR plan "collusion"116 and held that Skinner's reorganization plan was "unconfirmable" without the insurers' consent. ${ }^{117}$ Ultimately, the court found the reorganization plan so troublesome that it converted Skinner's chapter 11 reorganization into a chapter 7 liquidation. ${ }^{118}$ This case is an extreme example that illustrates both abuse of the mediation process and the limits of courts' willingness to look favorably upon mediation's unique ability to bridge jurisdictional boundaries and aid reorganizing debtors.

The case also illustrates some parties' total-and seemingly willful-lack of respect for the different roles of mediator and judge. Indeed, the case may be an example of the potential for creatively manipulative parties to use mediation's and mediators' ambiguous definitions to try to avoid the limits-jurisdictional, substantive, and procedural—established by law. ${ }^{119}$ Specifically, Skinner and its coProponents' proposed Alternative Dispute Resolution Process called upon the presiding judge to serve as "an arbitrator, mediator, or something else"120 yet "to make final binding determinations as to the validity and valuation of contested optin Asbestos Claims" ${ }^{121}$, thus requiring the court "in its official capacity, to finally liquidate such claims, and without any chance for review by another court." ${ }^{122}$ One problem with the parties' plan, of course, is that, by law, bankruptcy courts do not

${ }^{113}$ Id. at 423 .

${ }^{114}$ Id. at 421 .

${ }^{115} \mathrm{Id}$. at 418 .

${ }^{116} I d$. at 423

117 Id. at 426-27 (concluding confirmable plan could not be effectuated because of failure to obtain Insurers' consent, among other reasons).

${ }^{118}$ Id. Debtors who have run out of cash before their plan can be confirmed may themselves seek to convert their chapter 11 bankruptcy into a chapter 7 bankruptcy. See 11 U.S.C. § 1112 (b)(4) (2006) (listing causes for conversion to case under chapter 7). That does not seem to have been the case here. See In re Am. Capital Equip., 405 B.R. at 426-27 (stating conversion to chapter 7 was appropriate due to inability to effectuate confirmable plan).

${ }^{119}$ One cannot also help but be reminded of the Bush Administration's creation of (and Congress' apparent acquiescence in) military commissions to handle the Guantanamo detainees. See Boumediene v. Bush, 128 S. Ct. 2229, 2240-41 (2008) (holding Military Commissions Act of 2006 did not strip alien detainees of constitutional privilege of habeas corpus); Hamdan v. Rumsfeld, 548 U.S. 557, 559-60 (2006) (concluding military commission was not authorized by Congress and violated domestic and international); Hamdi v. Rumsfeld, 542 U.S. 507, 509 (2004) ("address[ing] the process that is constitutionally owed to one who seeks to challenge his classification as" an enemy combatant); see also Gregory S. McNeal, Institutional Legitimacy and Counterterrorism Trials, 43 U. RICH. L. REV. 967, 968 (2009) (arguing design of postSeptember 11th military commissions focused on effectiveness and not legitimacy). At the same time, it is important to acknowledge that Skinner and its Co-Proponents may have been motivated by an altruistic goal-e.g., to ensure that the claimants received some amount of recovery despite the insurers' resistance.

${ }_{120}$ See In re Am. Capital Equip., 405 B.R. at 426.

${ }^{221}$ Id. at 425 ("Provisions of the Alternative Dispute Resolution Process repeatedly call for this Court, in its official capacity, to make final binding determinations as to the validity and valuation of contested opt-in Asbestos Claims ....").

${ }_{122}$ See id. at 426 (explaining how debtor and Co-Proponent argued arbitration process requires court to liquidate claims in present case without chance of review by other courts). 
possess the authority to finally liquidate the sorts of claims that had been brought by the Asbestos Claimants. Such liquidation represents a "noncore proceeding"123 and as the Bankruptcy Court Judge M. Bruce McCullough went on to observe: "[T]he Court may only issue proposed findings of fact and conclusions of law to the district court with respect to noncore proceedings .... [T]his Court is powerless to make a final determination regarding the liquidation of any opt-in Asbestos Claims that are disputed."124

By simply changing the judge's title-from "judge" to "arbitrator, mediator, or something else"- the parties apparently hoped to avoid the bankruptcy court's inconvenient jurisdictional limits (and perhaps the need to pay the substantial fees that would be required for a private arbitrator, mediator or other type of neutral). And what would give the parties who had developed this Alternative Dispute Resolution Process the power to revoke the title of "judge" and replace it with "arbitrator, mediator, or something else"? Clearly frustrated, Judge McCullough summarized (and critiqued) the parties' arguments as follows:

The Court understands the Debtor and the Co-Proponents to respond...that (a) the Alternative Dispute Resolution Process constitutes part of a settlement of the Asbestos Claims, and (b) this Court's final liquidation of contested opt-in Asbestos Claims, because it is part of such process, can be done regardless of this Court's lack of authority to so finally liquidate outside of such process. By logical extension, this Court can only presume that, by arguing that this Court can so finally liquidate within the confines of the Alternative Dispute Resolution Process notwithstanding this Court's lack of authority to otherwise so finally liquidate, the Debtor and the Co-Proponents argue, as well, that this Court (a) is free to act (and will act when finally liquidating within the confines of the Alternative Dispute Resolution Process) other than as the presiding Court that it is vis-à-vis the instant bankruptcy case-for instance, as an arbitrator, mediator, or something else, and (b) may thereby transgress the legal confines of its official position. Unfortunately for the Debtor and the Co-Proponents, this Court is

\footnotetext{
${ }^{123}$ Id. at 425 ("[T]he liquidation of unliquidated personal injury tort claims, as are the opt-in Asbestos Claims, constitute(s) a noncore proceeding ....").

${ }^{124} \mathrm{Id}$. (observing Court is allowed to only issue "proposed findings of fact and conclusion of law ... with respect to noncore proceedings" and no power exists to makes determinations on liquidation of claims in dispute); see 28 U.S.C. $§ 157(b)(2)(B)$ (2006) ("Core proceedings include, but are not limited to allowance or disallowance of claims against the estate or exemptions from property of the estate, and estimation of claims or interests for the purposes of confirming a plan ... but not the liquidation or estimation of contingent or unliquidated personal injury tort ...."). It is conceivable, but beyond the scope of this Article, that the Debtor and its Co-Proponents may have claimed that an exception applied. See, e.g., In re UAL Corp., 310 B.R. 373, 379 (Bankr. N.D. Ill. 2004) (defining bankruptcy court's decision to time-bar personal injury claim as broad view of liquidation exception because it "effectively liquidate[d] the claim for purposes of distribution" and defining narrow view as specifically "fixing the amount of the claim").
} 
unaware of any legal authority that would permit it to so act while, at the same time, it also acts as the presiding Court. Furthermore, the relevant provisions of the Fifth Plan and CADP cited to above refer to this Court as "the Bankruptcy Court" when it makes its final determinations thereunder, which indicates to the Court that the Debtor and the Co-Proponents expect that this Court, when making final determinations within the confines of the Alternative Dispute Resolution Process, will only act within its official capacity as the presiding Court in the instant bankruptcy case. Acting in such official capacity, this Court, as set forth above, may not finally liquidate contested opt-in Asbestos Claims, and even to the extent that it can act with respect to such claims, such action will necessarily be reviewable by another court. ${ }^{125}$

The parties' position here-which would have allowed them and the court to "contract out" of the legal restrictions established by statute-was not necessarily unprincipled. Within the past few years, legal commentators have urged that statutes and court rules should be understood as merely "default" rules, subject to revision by parties who can imagine and implement dispute resolution procedures that are more responsive to their needs. ${ }^{126}$ The Supreme Court has recently dealt with parties arguing that they, not the Federal Arbitration Act, should be able to dictate the judicial standard of review to be used in determining whether to vacate an arbitral award. (The Court has rejected that argument. ${ }^{127}$ ) Professor Leonard Riskin and I have argued recently that courts should be willing to customize the mediation process. ${ }^{128}$ In recent years, as well, the line between private and public entities has become blurred. ${ }^{129}$ Further, there are some judges who have willingly

\footnotetext{
${ }^{125}$ In re Am. Capital Equip., 405 B.R. at 426 (emphasis added) (stating lack of "any legal authority" would allow court to act in two capacities). In a footnote, the court observed that the Debtor and its Co-Proponents could simply remove the court from the ADR Process and thus "rectify the flaw that the Court has just identified regarding such process." See id. at 426, 426 n.6. But the court added, "However, such removal of the Court would serve to make the Asbestos Claims Settlement, which incorporates the Alternative Dispute Resolution Process, even more unreasonable than it has already been determined to be by the Court." Id.

${ }^{126}$ See Symposium, Competing And Complementary Rule Systems: Civil Procedure and ADR, 80 NOTRE DAME L. REV. 481 (2005); see also Michael L. Moffitt, Customized Litigation: The Case for Making Civil Procedure Negotiable, 75 GEO. WASH. L. REV. 461, 462 (2007) ("I argue that the current set of procedural rules should be treated as default rules, rather than as nonnegotiable parameters."); Scott R. Peppet, Lawyers' Bargaining Ethics, Contract, and Collaboration: The End of the Legal Profession and the Beginning of Professional Pluralism, 90 lowA L. REV. 475, 519-20 (2005) (discussing stringency of immutable rules and potential bargaining and flexibility involved with default rules).

${ }^{127}$ See Hall St. Assocs. v. Mattel, Inc., 128 S. Ct. 1396, 1401 (2008) (agreeing with Ninth Circuit's holding "terms of the arbitration agreement controlling the mode of judicial review are unenforceable and severable").

${ }^{128}$ See Riskin \& Welsh, supra note 42, at 919 (discussing how courts should offer to "customize" mediation as new program).

${ }^{129}$ See Jody Freeman, Extending Public Law Norms Through Privatization, 116 HARV. L. REV. 1285, 1285 (2003) (advocating privatization as means to accomplish public utilitarian goals); see also Ellen Dannin, Red Tape 
become and called themselves 'mediators. ${ }^{130}$ Though well-intentioned and principled people can differ regarding the wisdom of this semantic choice when the mediator-judge does not and will not be required to preside over the case at trial, ${ }^{131}$ there can be no doubt of the coercive twist that a mediation has taken when the mediator and the presiding judge are the same person. ${ }^{132}$

So there is some sort of precedent for the arguments made by Skinner, its coProponents, and their lawyers. In 2009, however, in the Bankruptcy Court for the Western District of Pennsylvania, these parties took this concept too far. They tried to use arbitration, mediation "or something else" to force Skinner's insurers into the role of (unwilling) investors in Skinner's continued operation, and they tried to force a presiding judge into the role of an (unwilling) "alternative" neutral. ${ }^{133}$ Arguably, the parties' plan represented the creation of just another new, inoffensive hybrid process. To invoke a very old phrase, however, these parties tried to use mediation

Public-ization, and Public Values, 15 CORNell J.L. \& PUB. POL'Y 111, 151 (2006) (arguing against privatization as means for regulating public matters); Jon D. Michaels, All the President's Spies: PrivatePublic Intelligence Partnership in the War on Terror, 96 CAL. L. REV. 901, 904 (2008) (illustrating use of private sector to combat "War on Terror"). The law has evolved to permit "state action" claims against private parties engaged in a public function. See, e.g., Brentwood Acad. v. Tenn. Secondary Sch. Athletic Ass'n, 531 U.S. 288, 291 (2001) (holding private non-profit organization regulating high school sports was state actor); Richard C. Reuben, Constitutional Gravity: A Unitary Theory of Alternative Dispute Resolution and Public Civil Justice, 47 UCLA L. REV. 949, 993-1016 (2000) (applying state action doctrine to private conduct in ADR context).

${ }^{130}$ Nancy A. Welsh \& Bobbi McAdoo, Eyes on the Prize: The Struggle for Professionalism, DISP. RESOL. MAG, Spring 2005, at 13, 14 (disclosing judge's response to confidentiality concerns raised when judge is both mediator and adjudicator).

${ }^{131}$ See Elizabeth S. Stong, Some Reflections from the Bench on Alternative Dispute Resolution in Business Bankruptcy Cases, 17 AM. BANKR. INST. L. REV. 387, 395 (2009) (suggesting parties would be less willing to take unreasonable positions before judge serving as mediator). The line dividing mediations from judicial settlement conferences, for example, may be a fine one. See generally Wayne D. Brazil, Hosting Settlement Conferences: Effectiveness in the Judicial Role, 3 OHIO ST. J. ON DISP. RESOL. 1, 16-30 (1987) (discussing several different formats of judicial settlement conferences); Carrie Menkel-Meadow, For and Against Settlement: Uses and Abuses of the Mandatory Settlement Conference, 33 UCLA L. REV. 485, 510-11 (1985) (describing judges' role at many settlement conferences as hybrid form of mediation-arbitration).

${ }^{132}$ See Welsh \& McAdoo, supra note 130, at 14 (demonstrating difficulty for parties' to object to trial judge serving as mediator); see also James J. Alfini, Risk of Coercion Too Great: Judges Should Not Mediate Cases Assigned to Them for Trial, DISP. RESOL. MAG., Fall 1999, at 11, 11 (supporting judges serving as mediators unless judge is presiding over parties' trial); Frank E.A. Sander, A Friendly Amendment, DiSP. RESOL. MAG., Fall 1999, at 21, 21 (concurring with Professor Alfini). This innovation particularly raises serious questions about the application of confidentiality or the mediation privilege to a process called mediation. See UNIF. MEDIATION ACT, § 3(b)(3) 7A Pt. III U.L.A. 110 (2003) (providing Act does not apply to mediation "conducted by a judge who might make a ruling on the case").

${ }^{133}$ They also tried to force the Asbestos Claimants into "volunteering" to assign $20 \%$ of their awards, upon electing to use the Alternative Dispute Resolution Process. There are some echoes here of the arguments made by employers, credit companies and others who insert mandatory arbitration clauses in their boilerplate agreements with employees, consumers, etc. See Thomas E. Carbonneau, Arguments in Favor of the Triumph of Arbitration, 10 CARDOZO J. CONFLICT RESOL. 395, 413 (2009) (summarizing party inequality problems present in arbitration arising from form clauses); Jean Sternlight, As Mandatory Binding Arbitration Meets the Class Action, Will the Class Action Survive?, 42 WM. \& MARY L. REv. 1, 12 (2001) (illustrating consumer and employee opposition to mandatory arbitration in contracts of adhesion); see also Christopher R. Drahozal, "Unfair" Arbitration Clauses, 2001 U. ILL. L. REv. 695, 696-97 (2001) (outlining academic criticisms of consumer arbitration clauses). 
to 'have their cake and eat it too.' A careful judge, ${ }^{134}$ apparently alerted by skilled lawyers representing self-interested insurers, ${ }^{135}$ carefully examined the details of the proposed plan and its consequences and stopped the potential abuse of mediation, ADR more generally, the bankruptcy court, and federal statutes. ${ }^{136}$

In contrast, other cases signal that at least some bankruptcy judges do not fully understand the appropriate limits of the mediator's role. Indeed, some courts sometimes seem to view mediators largely as substitutes for trustees, special masters, arbitrators, magistrates or examiners-none of whom is a judge but all of whom have an evaluative or adjudicative function similar to that of a judge. Only mediators' enhanced ability to protect the confidentiality of what is said, done, and produced during the mediation process seems worth notice-and use. ${ }^{137}$

In 1998, for example, the Bankruptcy Court for the Middle District of Florida approved a joint motion to appoint a mediator. ${ }^{138}$ In its opinion, the Bankruptcy

134 Reminiscent of Justice Scalia, with his dissent in Hamdi, noting that neither the plurality of the Supreme Court nor Congress nor the Executive had used or applied the law appropriately. Hamdi v. Rumsfeld, 542 U.S. 507, 576 (2003) (Scalia, J., dissenting) ("There is a certain harmony of approach in the plurality's making up for Congress's failure to invoke the Suspension Clause and its making up for the Executive's failure to apply what it says are needed procedures - an approach that reflects what might be called a Mr. Fix-it Mentality. The plurality seems to view it as its mission to Make Everything Come Out Right, rather than merely decree the consequences ....").

${ }_{135}$ Indeed, the court explicitly referenced the Insurers' arguments. In re Am. Capital Equip., 405 B.R. 415 , 422-23 (Bankr. W.D. Pa. 2009) ("Debtor can obtain . . proceeds . . . only if the Debtor's defense - or, more accurately, the Insurers' defense of the Debtor - with respect to such claim(s) is unsuccessful."). It is well beyond the scope of this Article to determine the strength of many of those arguments, particularly: whether Pennsylvania law was applicable here; whether Pennsylvania law effectively restricts parties from entering into settlements without their insurers' consent; whether such a settlement by the parties may be deemed unreasonable simply because the insurer has refused to pay such claims for 20 years, etc. See id. at 419-22 (discussing whether state law restricts debtor's ability to settle without insurers' consent and whether settlement was reasonable). I am also unable to determine the extent to which the judge's careful analysis was based upon the work of an astute judicial clerk.

${ }^{136}$ This cautionary tale may be useful fodder for those currently arguing that coverage of the law related to ADR should be "mainstreamed" in the law school curriculum. See id. at $\mathbf{4 2 5}$ (noting how settlement had to be rejected due to its creation through unintended use of alternative dispute resolution).

${ }_{137}$ See Nancy A. Welsh, Mediation Confidentiality in the U.S., in MEDIATION EN VERTROUWELIJKHEID (MEDIATION AND CONFIDENTIALITY) (Hester Montree and Alexander Oosterman, eds., 3d ed., 2009); see also LEONARD L. RISKIN ET AL., DISPUTE RESOLUTION AND LAWYERS 328-41 (4th ed. 2009) (discussing how mediation requires confidentiality to promote effective resolution between parties and how Uniform Mediation Act of 2003 provides mediation communications are neither subject to discovery nor admissible in evidence except in very limited circumstances); Carrie Menkel-Meadow, Public Access to Private Settlements, in WHATS FAIR: ETHICS FOR NEGOTIATORS 507, 507, 511 (Carrie Menkel-Meadow \& Michael Wheeler eds., 2004) (analyzing how despite movement to require disclosure of settlement agreements dealing with issues of public concern, "confidentiality and secrecy are often needed" to allow for effective resolution of disputes when disclosure may damage parties involved and noting how potential for this damage promotes confidentiality, privacy, and immunity in the mediation setting); Ellen $\mathrm{E}$. Deason, The Need for Trust as a Justification for Confidentiality in Mediation: A Cross-Disciplinary Approach, $54 \mathrm{U}$. KAN. L. REV. 1387, 1387 (2006) (observing importance of confidentiality in mediation and describing how mediator's enhanced ability to protect mediation communications is apparent from state legislatures across our nation taking steps to protect confidentiality in this setting).

${ }^{138}$ See In re Sargeant Farms, Inc., 224 B.R. 842, 844 (Bankr. M.D. Fla. 1998) (appointing mediator upon joint motion of parties to facilitate resolution of various issues within chapter 12 Bankruptcy case including valuation of debtor's property after parties were unable to select mediator pursuant to initial Court Order). 
Court established the following procedures and terms for the mediation: the parties were to split the cost of the mediator's services, who was to be compensated based upon the magnitude and complexity of the proceedings; the mediator was to have the authority to order depositions or interrogatories to any person or entity that might possess information determined by the mediator to be necessary; and the mediation was to be covered by a broad confidentiality rule. ${ }^{139}$ The court specified that its confidentiality provisions did not mean that evidence otherwise produced could not be used in "any further hearing in the case" ${ }^{140}$ but confidentiality was to protect "what the parties and the mediator discuss[ed] and present[ed]"141 in the course of the mediation. Giving a mediator the authority to order discovery-an authority generally reserved for judges, trustees, special masters, magistrates, and arbitrators - and coupling it with confidentiality covering all of what was to be discussed and presented in mediation seems to be a recipe for confusion and abuse of process. ${ }^{142}$

Similarly, when the Bankruptcy Court for the Northern District of Illinois ${ }^{143}$ upheld a mediation and binding arbitration clause within a contract for the provision of auditing services, the court appeared to expect the mediator to possess the authority of an arbitrator. ${ }^{144}$ The court appointed a trustee who filed an adversary complaint for professional negligence and breach of contract against Checkers, the

139 See id. at $847-48$ (determining mediation procedures will follow above guidelines and all other requirements delineated in Local Rule 9019-2 of United States Bankruptcy Court for Middle District of Florida).

${ }^{140}$ Id. at 848 (stating producible evidence could be used at further hearings despite court's that any exception to confidentiality under Local Rule 9019-2 would not apply in bankruptcy).

${ }_{141}^{1}$ Id.

${ }^{142}$ See supra note 137; see also Ellen E. Deason, Enforcing Mediated Settlement Agreements: Contract Law Collides with Confidentiality, 35 U.C. DAVIS L. REV. 33, 71-73 (2001) (discussing confusion and possible abuse in case where United States District Court for Northern District of California created its own exception to confidentiality rules, allowing mediator to testify due to allegations of duress and in interest of justice, which "justified the harms to the interests underlying the mediation privilege that would result from disclosure," despite fact California courts are not authorized to create exceptions to confidentiality by weighing necessity of disclosure).

${ }_{143}$ See In re Griffin Trading Co., 250 B.R. 667, 672-73 (Bankr. N.D. Ill. 2000) (ordering stay of adversary proceeding between trustee and accounting firm when plain language of contract between debtor and accounting firm provided differences should be resolved by mediation or arbitration).

${ }^{144}$ See id. at 673 (citing AT\&T Techs., Inc. v. Commc'ns Workers of Am., 475 U.S. 643, 648, 650 (1986)) (noting heavy presumption in favor of arbitration and stating arbitrability will be left to arbitrator when parties have explicitly agreed to arbitration provision). Along with the mediation and arbitration clause, the contract set forth specific services that Checkers, an accounting firm, would perform for Griffin, the debtor. The contract included, among other provisions, the following: 1) auditing responsibilities; 2) making "specific inquires of management and others about the representations embodied in the financial statement;" 3) examining Griffin's control system to ensure the safety of assets and that "transactions are executed in accordance with management's authorization." $I d$. at 670 . The contract also stated that any "differences concerning our services or fees" will be sent to mediation, then arbitration. Id. at 672 . During the time Checkers was auditing Griffin, Griffin's CFO was trading stocks with company money. Id. at 670 . Although the auditors asked the CFO about a suspicious account, they did not investigate further. Id. A year after the audit, Griffin filed for chapter 7 protection after the CFO came forward and admitted to losing approximately $\$ 2,000,000$. Id . at 671 . Once appointed, the trustee filed a complaint against Checkers for professional negligence and breach of contract. $I d$. at 669 . 
organization that provided the auditing services. ${ }^{145}$ The court held that the plain language of the contract required the use of mediation, then arbitration, and, therefore, the parties were bound by the clause ${ }^{146}$ More significantly for the purposes of this Article, the court stated "if the parties clearly and unmistakably agree to arbitrate, then the question of arbitrability is for an arbitrator." ${ }^{147}$ Presumably, the court also understood that the question of mediability would be for the mediator.

Some courts' apparent confusion regarding the appropriate limits that should be placed upon the role of the mediator also has emerged in a couple of cases in which courts have had the opportunity to require and affirm the determinations of mediators. In Hickox v. Friedland (In re HBLS, L.P.), ${ }^{148}$ the Bankruptcy Court for the Southern District of New York determined that a dispute arising out of a mediation agreement should be submitted to the mediator for a decision and the court then deferred to that decision. ${ }^{149}$ The facts, as so often seems to be the case in corporate reorganizations, are a little complicated. In 1993, HBLS filed for chapter 11 bankruptcy. ${ }^{150}$ Charles Hickox ("Hickox") was a shareholder of HBLS and two other corporations, LIR and MBM. ${ }^{151}$ The three corporations ran a resort together and were known as "Resort Entities." ${ }^{152}$ Prior to HBLS's chapter 11 filing, it was in litigation with another group headed by Dion Friedland (for the purposes of this Article, also known as "Friedland Group"). ${ }^{153}$ With the help of a court-appointed mediator, HBLS and Friedland Group reached a settlement of their lawsuit. Included in the agreement was a "resolution clause" that stated that "any dispute or determinations arising under, relating to or in connection with this Settlement Agreement, its interpretation, performance or enforcement shall be determined solely and exclusively by the Mediator, whose decision shall be final and binding and non-appealable." ${ }^{154}$

The Resort Entities defaulted on a payment agreed on in the "Settlement Agreement" and after a number of disputes, the mediator made a final award to the Friedland Group. ${ }^{155}$ Under the Settlement Agreement, the final award was to have the same force and effect as a final arbitration award due to the language of the "resolution clause."156 The same day that the bankruptcy court adopted the

\footnotetext{
${ }^{145}$ Id. at $669-70$.

${ }^{146} \mathrm{Id}$. at 673 . "The heavy presumption in favor of arbitration shall be extended when there is a possibility that a dispute is covered by an existing, valid arbitration clause." Id.

${ }^{147} \mathrm{Id}$. at 674 (citing $A T \& T, 475$ U.S. at 649 ).

${ }^{148} 01$ Civ. 2025, 2001 U.S. Dist. LEXIS 19112 (S.D.N.Y. Nov. 13, 2001).

149 Id. at $* 17-18$.

${ }^{150} \mathrm{Id}$. at $* 4-5$.

151 Id. at $* 5$.

152 Id. at $* 5$

${ }^{153} I d$. at *4 (recalling HBLS had been sued for defaulting under stock purchase agreement with Friedland).

154 Id. at $* 8$.

${ }^{155} \mathrm{Id}$. at $* 9-12$.

${ }^{156}$ Id. at $* 8$ (noting Settlement Agreement "shall be determined solely and exclusively by the Mediator, whose decision shall be final and binding and non-appealable").
} 
mediator's final award, Friedland moved for entry of a deficiency judgment. ${ }^{157}$ Hickox opposed this motion as against LIR and MBM, claiming that under the Settlement Agreement, only HBLS was liable to Friedland Group. After some extended procedural wrangling, ${ }^{158}$ the Bankruptcy Court submitted the specific issue of LIR's and MBM's liability to the mediator. The mediator wrote a decision declaring HBLS, LIR and MBM jointly and severally liable under the Settlement Agreement. The bankruptcy court confirmed the mediator's award on the basis that it was not in manifest disregard of the law ${ }^{159}$ and reinstated a deficiency judgment that it had entered earlier.

Hickox appealed to the district court, claiming that by seeking a deficiency judgment, Friedland had waived the right to have the mediator arbitrate ${ }^{160}$ the claim and also that the mediator's award was in error. As to the latter issue, the district court determined that it had to "decide de novo whether the mediator's ruling was in manifest disregard of the law." 161 According to the court, there was "no basis to overturn the mediator's award" because: 1) Hickox had attacked the Settlement Agreement only on the merits and failed to allege the mediator's manifest disregard of the law; 2) "the Mediator's interpretation of the terms of the Settlement Agreement is not so clearly inconsistent with the Agreement's plain terms that the Mediator could be said to have manifestly disregarded the law;" and 3) the Mediator had firsthand knowledge of the parties' spirit and intent and had found that the parties had conducted themselves as if they intended to make LIR and MBM liable. ${ }^{162}$

The most notable points here are that both the bankruptcy court and the district court relied on a "mediator" to arbitrate and then applied a deferential ${ }^{163}$ standard of review that has been fashioned specifically for arbitration to this "mediator's award."

Similarly, a court upheld a mediator's determination made in In re EaglePitcher Industries, Inc. ${ }^{164}$ The creditors and debtor in a chapter 11 proceeding had

157 Id. at $* 13$.

158 Id. at ${ }^{*} 10-11$ (highlighting liability dispute over expenses incurred from collateral shares sale by Mediator). The Bankruptcy Court rejected Hickox's initial argument and entered a deficiency judgment declaring HBLS, LIR, and MBM jointly and severally liable to Friedland. Id. at *15. Hickox appealed this ruling to the United States District Court for the Southern District of New York. Id. Due to a lack of clarity in the record regarding the presentation of the issue to the mediator and the basis for the Bankruptcy Court's decision, the District Court remanded the case back to the Bankruptcy Court, which then held another hearing, specifically submitted the issue of LIR's and MBM's liability to the mediator, and ultimately affirmed the mediator's decision finding joint and several liability. Id. at *16-18.

${ }^{159}$ Id. at $* 31-32$.

${ }^{160} \mathrm{Id}$. at $* 18$. This is a bit oxymoronic.

${ }^{161} I d$. at $* 10$.

${ }^{162}$ Id. at $* 10-12$.

163 See Hall Street Assocs. v. Mattel, Inc., 128 S. Ct. 1396, 1404 (2008) (calling "manifest disregard" into question by stating that it may not be new ground for review but way to refer to all of standards collectively); Bosack v. Soward (In re Arbitration Between Bosack), 573 F.3d 891, 899 (9th Cir. 2009) ("Arbitrators exceed their powers when they express a 'manifest disregard of law,' or when they issue an award that is 'completely irrational."').

164176 B.R. 143 (Bankr. S.D. Ohio 2004). 
difficulties creating a reorganization plan, so the court appointed a "mediator" to determine if the negotiations were at an impasse. With the help of the mediator, the parties began to make progress towards a consensual plan. As part of the process, the mediator met with "the active parties in sharpest disagreement." ${ }^{165} \mathrm{He}$ did not involve two of the creditor committees. When the agreement between the "active parties" was announced to the other two committees, one committee made a counterproposal. ${ }^{166}$ The mediation stalled. The mediator indicated his intent to send a letter to the judge stating "at least for the time being, negotiations are at an impasse." ${ }^{167}$ Several weeks later, however, the mediator sent a "clarifying" letter to counsel stating that they "should not consider those letters as declaring an impasse." ${ }^{168}$ In the meantime, the two excluded creditor-committees had filed motions aimed at ending the period of exclusivity. ${ }^{169}$ In order to succeed on these motions, they were required to show cause, such as delay by the debtor as a tactical device or another action in bad faith. One committee argued that it had been treated unfairly by being left out of the mediation and that this constituted sufficient cause. ${ }^{170}$ The court responded: "In the present bankruptcy case, all of the constituencies acquiesced both in the initiation of mediation, and the selection of the mediator. The mediator has expressed the view that impasse has not occurred . . . . This court sees no reason to question the judgment of the mediator on this score." ${ }^{171}$ The standard of review used by the court here is unclear but it certainly appears deferential. The court upheld the determination of the mediator and refused to terminate the period of exclusivity. ${ }^{172}$

The bankruptcy cases described here suggest that bankruptcy courts and repeat players are exhibiting some confusion regarding the appropriate roles of mediation and mediators. Further, these cases suggest that bankruptcy courts and repeat players may wish to seek neutrals who possess both consensual skills and adjudicative authority. This Article will now turn to the evolution of divorce and child custody mediation and the role of "traditional neutrals" in that context, who may be mining the courts' experience with mediation in order to develop innovative and tailored hybrid procedures.

\footnotetext{
${ }^{165} \mathrm{Id}$. at 146.

${ }^{166} \mathrm{Id}$. (noting Official Unsecured Creditors' Committee "responded with a counterproposal, the contents of which, consistent with the requirement of the mediation order that the court not be informed of the proceedings before the mediator" were not disclosed to court).

${ }^{167} I d$.

${ }^{168} \mathrm{Id}$.

169 Id. at 146,148 (noting objective of both motions was to propose competing plans). One was a motion "For Order Terminating or Modifying Exclusivity Period to Permit Filing of Alternative Reorganization Plan," and the second was a motion "To Declare Mediation Impasse." Id. at 144-45.

${ }^{170} I d$. at 146 (claiming entitlement to level playing field in mediation plan).

${ }^{171} \mathrm{Id}$. at 148 .

${ }^{172} I d$. at $148-49$ (finding no cause to doubt assessment of mediator since all parties agreed to both mediation and selection of mediator).
} 


\section{Evolution of Divorce AND CHILd CUSTODY MEDiation}

For many years, divorce and child custody mediation was viewed as the one area of court-connected mediation that could be characterized as primarily-though not exclusively-elicitive or facilitative. ${ }^{173}$ Particularly in custody matters, it made so much sense that the parents would want to play the primary role in determining how to care for and support their children after a divorce-and it made so much sense that the courts would want to support parents in this preference. ${ }^{174}$ Research has affirmed that divorce and child custody mediation results in higher rates of compliance, fewer returns to the courts with post-divorce disputes, and more significant relationships between children and both of their parents. ${ }^{175}$

Recently, however, a few researchers ${ }^{176}$ and well-respected mediation advocates and leaders ${ }^{177}$ have begun to highlight concerns and challenges for court-connected divorce and child custody mediation. It appears that the process has evolved into something that is not as consensual as it once was. ${ }^{178}$ Largely, this evolution is due

${ }^{173}$ See Nancy A. Welsh, Reconciling Self-Determination, Coercion, and Settlement in Court-Connected Mediation, in DIVORCE AND FAMILY: MEDIATION: MODELS, TECHNIQUES, AND APPLICATIONS 420 (Folberg, et. al eds., 2004) [hereinafter Welsh, Reconciling Self-Determination]. But see Isolina Ricci, Court-Based Mandatory Mediation: Special Considerations, in DIVORCE AND FAMILY: MEDIATION: ModELS, TECHNIQUES, AND APPLICATIONS 397 (Folberg, et. al eds., 2004) (describing "recommending" model of mediation in California, which made divorce and child custody mediation mandatory in 1981).

${ }^{174}$ See Ann L. Milne, Mediation and Domestic Abuse, in DIVORCE AND FAMILY MEDIATION: MODELS, TECHNIQUES, AND APPLICATIONS 304 (Folberg, et al. eds., 2004).

${ }^{175}$ See Joan B. Kelly, A Decade of Divorce Mediation Research: Some Answers and Questions, 34 FAM. \& CONCILIATION CTS. REV. 373, 377 (1996) (stating mediation agreements have higher rate of compliance than adversarial process agreements); Joan B. Kelly, Family Mediation Research: Is There Empirical Support for the Field?, 22 CONFLICT RESOL. Q. 3, 28 (2004) [hereinafter Kelly, Family Mediation] ("Mediation has given evidence of its power to settle complex, highly emotional disputes and reach agreements that are generally durable."); Peter Salem, The Emergence of Triage in Family Court Services: The Beginning of the End for Mandatory Mediation?, 47 FAM. CT. REV 371, 373-74 (2009) (discussing advantages of mediation such as quick settlement, agreement satisfaction, and improved family relationships); see also Ralph A. Peeples et al., It's the Conflict, Stupid: An Empirical Study of Factors that Inhibit Successful Mediation in High-Conflict Custody Cases, 43 WAKE FOREST L. REV. 505, 528 (2008) (finding agreements reached through mediation were more stable than court orders).

${ }^{176}$ See Salem, supra note 175 , at 374 (citing CONNIE J. BECK \& BRUCE DENNIS SALES, FAMILY MEDIATION: FACTS, MYTHS, AND FUTURE PROSPECTS (2001)) (noting limited research that has been done on family mediation); see also Connie J. Beck et al., Research on the Impact of Family Mediation, in DIVORCE AND FAMILY MEDIATION: MODELS, TECHNIQUES, AND APPLICATIONS 447 (Jay Folberg, et. al eds., 2004).

${ }^{177}$ See Hon. Leonard Edwards, Comments on the Miller Commission Report: A California Perspective, 27 PACE L. REV. 627, 628, 656 (2007) (advocating mediation for New York while identifying challenges in California, including one hour mediations as result of resource and funding issues); Kelly, Family Mediation, supra note 175, at 29 (acknowledging reduced time for mediation); Salem, supra note 175, at 385-86, $385 \mathrm{n}$. 1 (discussing differing methods of alternative dispute resolution in family setting employed by multiple jurisdictions in different regions and suggesting adaptation of type of mediation used based on context); Donald T. Saposnek, Commentary: The Future of the History of Family Mediation Research, 22 CONFLICT RESOL. Q. 37 (2004) (response to article by Joan Kelly articulating mediation "works, but not quite as comprehensively as ... [was] hoped"). But see Steve Baron, A Response to Peter Salem's Article, 48 FAM. CT. REv. (forthcoming 2010); Hugh McIsaac, A Response to Peter Salem's Article, 48 FAM. CT. REV. (forthcoming 2010).

${ }^{178}$ Or perhaps simply appeared to be. See Salem, supra note 175 , at 378 (noting outside findings 
to the phenomenon of increasing and more difficult caseloads, static or reduced hiring of mediators, static or reduced court funding, and no reduction in the public's or courts' expectations for the prompt disposition of cases. ${ }^{179}$

The divorce and child custody mediation that produced such positive results in the 1980s took time-perhaps five to six hours per case-with each mediation session lasting a couple of hours. Increasingly, due to increased caseloads and static hiring, divorce and child custody mediations must be completed in an hour. ${ }^{180}$ Inevitably, in order to achieve settlement, mediators are tempted to adopt more evaluative, directive and even coercive approaches. ${ }^{181}$ There is a possibility that these settlements still reflect the parents' "self-determination," but that seems unlikely.

In addition, the people being served by divorce and child custody mediation may be becoming more difficult-and expensive-for courts to handle. ${ }^{182}$ Throughout the country, courts note the increase of pro se litigants. ${ }^{183}$ More parties require translation services. ${ }^{184}$ There is also more reporting of domestic abuse, child abuse, and substance abuse in divorce and child custody matters. ${ }^{185}$

Finally, though, mediation is no longer the only process besides traditional litigation that family courts can provide. This is especially true for disputing parents who want, or can benefit from, the opportunity to be directly involved in the reorganization of their family but who also need help with this profoundly important change. In some courts, ${ }^{186}$ caring and pragmatic court administrators,

\footnotetext{
suggesting mediators are pushing settlement rather than providing options).

${ }^{779}$ See id. at 377 (discussing "question as to whether court-connected mediation continues to deliver on the promise of family self-determination").

${ }_{180}$ See id. at 379 (referencing opinion that insufficient time is being offered for parents to effectively resolve differences) (citation omitted); see also Edwards, supra note 177, at 650 ("Some mediation services can only offer the parents an hour or even less to resolve their differences."); Kelly, Family Mediation, supra note 175, at 29 (suggesting client dissatisfaction with mediation might "reflect[ ] a more rushed or coercive mediation process").

${ }^{181}$ See Salem, supra note 175, at 378-79 (discussing directive and evaluative approaches for settlements in divorce and child custody cases to deal with timing issues); see also Welsh, Reconciling Self-Determination, supra note 173, at 427-34 (describing Florida case of Vitakis-Valchine v. Valchine).

${ }^{82}$ See Salem, supra note 175, at 381-82 (acknowledging families are exposed to increased financial burdens when they are required to participate in unneeded mediation).

${ }^{183}$ Kimberlianne Podlas, Broadcast Litigiousness: Syndi-Court's Construction of Legal Consciousness, 23 CARDOZO ARTS \& ENT. L.J. 465, 498 (2005) (acknowledging increasing number of pro se litigants).

${ }^{184}$ See JAMES C. DUFF, ADMINISTRATIVE OFFICE OF THE U.S. COURTS, 2007 ANNUAL REPORT OF THE DIRECTOR 35 (2007) (noting 17\% increase in number of court events requiring interpreters across nation from 2006 to 2007).

${ }^{185}$ See Saposnek, supra note 177, at 38 (discussing increase in serious problems reported during divorce cases from 1980s to present day). Importantly, it is not clear whether the actual incidence of these problems is increasing, whether people are more willing to admit to dealing with such issues, or whether court personnel are more likely to detect issues of abuse now than previously. See JUDICIAL COUNCIL OF California, Administrative OfFicer of the COURTS, Research Update: Difficult Cases in CALIFORNia COURT-BASED CHILD Custody MEDIATION 2 (2003) (reporting lack of systematic method used to collect statistical information regarding domestic violence and drug abuse in divorce mediation).

${ }^{186}$ See, e.g., JUDICIAL COUNCIL OF CALIFORNIA, supra note 185 , at $9 \mathrm{n} .3$ (stating only $35 \%$ of California family courts provide ADR options besides mediation). It is important to note that these alternatives are not
} 
counselors, and judges have been able to develop new alternatives that explicitly bridge the divide between elicitive/facilitative/consensual approaches in mediation on the one hand and evaluative/directive/adjudicative procedures approaches on the other. Examples include:

- Conflict resolution conference-a "confidential dispute resolution process [that] . . . is more directive than mediation, and may include information gathering and recommendations on the part of the family relations counselor"187

- Non-confidential dispute resolution and assessment-a "hybrid process that includes negotiation and encourages agreements but, if necessary, includes assessment, child interviews, collateral information gathering and recommendations to the court" ${ }^{188}$

- Early neutral evaluation-a "confidential abbreviated process in which parties, accompanied by lawyers if represented, present their case to two evaluators who provide an early indication of their likely recommendation with the caveat that such recommendations are based on parties' ability to verify their claims and allegations" ${ }^{189}$

- Collaborative law-"an interest based negotiation approach to lawyer-assisted settlement negotiations that frequently incorporates mental health and financial professionals" as well as direct party participation in settlement negotiations and in which "lawyers withdraw if the case does not settle and proceeds to trial"190; and

available in all courts. For a variety of reasons, many courts can offer only mediation as an alternative. My thanks to Peter Salem for this clarification.

${ }^{187}$ Salem, supra note 175, at 385 n.1; see Peter Salem et al., Triaging Family Court Services: The Connecticut Judicial Branch's Family Civil Intake Screen, 27 PACE L. REV. 741, 753 (2006) (describing conflict resolution conference as "eight-week confidential service that blends the negotiation and mediation processes" in which no findings or recommendations are revealed by counselors if agreement is not reached).

${ }^{188}$ Salem, supra note 175 , at $386 \mathrm{n} .1$ (citing Clarence Cramer, personal communication July 31, 2008). This hybrid, though very intriguing, has recently been discontinued. See E-mail from Peter Salem to Nancy Welsh (Sept. 27, 2009) (on file with author). The reasons for such discontinuance are unclear.

${ }_{189}$ Salem, supra note 175, at 386 n.1; see Daniel Forman, Improving Asylum-Seeker Credibility Determinations: Introducing Appropriate Dispute Resolution Techniques into the Process, 16 CARDOZO J. INT'L \& COMP. L. 207, 234 (2008) (stating neutral evaluators may also assist in "developing a discovery schedule, streamlining issues for trial, or planning other settlement events"); Yvonne Pearson et al., Early Neutral Evaluation: Applications to Custody and Parenting Time Cases Program Development and Implementation in Hennepin County, Minnesota, 44 FAM. CT. REV. 672, 673 (2006) (describing Early Neutral Evaluation (ENE) as "2- to 3-hour" session in which each side, represented by its own attorney, present its case to two neutral evaluators, "one male and one female," who ask each side questions and give feedback to parties before attempting settlement negotiations); Frank E.A. Sander \& Lukasz Rozdeiczer, Matching Cases and Dispute Resolution Procedures: Detrained Analysis Leading to a Mediation-Centered Approach, 11 HARV. NEGOT. L. REV. 1, 13, 20 (2006) (discussing helping parties reach settlement or preparing parties for trial based on strengths and weaknesses of each side's case as responsibilities of ENE evaluators).

${ }^{190}$ Salem, supra note 175 , at 386 n.1; see Susan Daicoff, Collaborative Law: A New Tool for the Lawyer's Toolkit, 20 U. FLA. J.L. \& PUB. POL'Y 113, 120-21 (2009) (describing contractual relationship among parties and lawyers in which attorneys agree to withdraw should case not settle and parties agree to "negotiat[e] in 
- Cooperative negotiation agreements or cooperative law-_lawyerassisted settlement negotiations that typically incorporate voluntary information sharing, interest based negotiation, direct involvement of clients, confidential negotiations, children's best interest as an essential ingredient and disincentives (not including withdrawal of counsel) to litigation." ${ }^{191,192}$

These procedures involve custody investigators, court staff, lawyers-the "traditional neutrals" and professionals who may have felt (or have actually been) supplanted by mediators. The "traditional neutrals" did not go away. They regrouped, learned new approaches and skills, and adapted to respond to both mediation's challenge and the needs of the many parties still turning to the courts for help.

Some innovative family courts seem to be adopting something akin to the multi-door courthouse. For example, some courts that formerly required all divorcing parties to attempt mediation before they could proceed to other, more intrusive and adjudicative procedures, now require divorcing parties to engage in an interactive process with a trained court services counselor. Together, the parties and the counselor use a research-based screening and assessment instrument, supplemented by the counselor's clinical judgment, to determine the most appropriate procedure. ${ }^{193}$ This is called the "triage" model of delivering court services, as contrasted with the "tiered" service model. ${ }^{194}$

It may seem that all of this innovation represents a repudiation and rejection of mediation. It is not. Rather, it represents a recognition that mediation is not, cannot

good faith, voluntarily disclos[e] information, maintain[ ] confidentiality . . . and refrain[ ] from litigative motions"); John Lande \& Gregg Herman, Fitting the Forum to the Family Fuss: Choosing Mediation, Collaborative Law, or Cooperative Law for Negotiating Divorce Cases, 42 FAM. CT. REV. 280, 282-83 (2004) (elaborating upon process in which both sides enjoy strong advocacy while striving for collaboration through negotiation with help of coaches and specialists who can educate and aid parties during negotiation); see also MACFARLANE, supra note 60 , at 89 (positing nature of collaborative law retainer agreement shifts attorneys' strategy and focus by taking option of litigation off of table); Lande, supra note 65, at 626-28 (citing "disqualification agreement" as lynchpin of increasingly popular ADR method).

${ }^{191}$ Salem, supra note 175, at 386; see Lande, supra note 65, at 632 n. 62 ("Cooperative Law is a process that includes the features of $\mathrm{CL}$ other than the disqualification agreement.").

${ }^{192}$ Other more innovative procedures that do not quite bridge this divide include interdisciplinary arbitration panels, psycho-educational programs, and parenting coordination. Salem, supra note 175, at 371 .

${ }^{193}$ See id. at 380 ("In a triage system, parents may complete an initial screen and/or participate in an interview, and agency representatives then help identify the service they believe will best meet the needs of the family. The determination of services may be based on a combination of pre-determined criteria, clinical judgment and feedback from parents . . . ."); Salem et al., supra note 187, at 757-64 (2007) (outlining Connecticut's Family Civil Intake Screen and describing empirical bases and how counselors exercise clinical judgment in process); see also Nancy A. Welsh, The Future of Mediation: Court-Connected Mediation in the U.S. and the Netherlands Compared, I FORUM VOOR CONFLiCT MANAGEMENT 19, 21 (2007) [hereinafter Welsh, Future of Mediation] (noting some "Dutch judges in the pilot sites . . . distributed a 'self test' to all parties to encourage them to consider whether mediation might be appropriate for their case.").

${ }^{194}$ See Salem, supra note 175, at 371-372 (explaining arguments in favor and against triage model in comparison to tiered model). 
be, and never should have been expected to be, the cure-all for every ill. Like most organisms, mediation requires structural protection in order to achieve its potential-e.g., sufficient time for deliberation; mediators who are not afraid of the consequences that may be visited upon them if mediating parties refuse to settle; authority to refuse service to parties who have demonstrated their inability or unwillingness to benefit from participation in the process; and complementary services to which mediators may refer.

Mediation blazed the way in creating an alternative to traditional litigation in the family courts, but it has now been joined by other procedures, customized to respond to the characteristics and circumstances of those who must use them ${ }^{195}$ in order to receive judicial permission to divorce and parent their children. ${ }^{196}$ In at least some pioneering courts, there are now several paths to the resolution of divorce and child custody matters, hopefully with all processes sharing a commitment to the provision of an experience of justice. ${ }^{197}$

\section{LESSONS FOR BANKRUPTCY MEDIATION}

There is no doubt that mediation offers unique advantages for the resolution of disputes - the ability to deal with all of the issues, not just those that come within the jurisdiction of a particular court; the opportunity to exploit the parties' knowledge and skills, rather than relying exclusively on the lawyers, to develop creative, customized solutions; the opportunity to experience those moments of grace when people suddenly see each other and understand something about each other and their situation that they did not understand before.

And yet, the "fit" between mediation-especially the facilitative, elicitive, and transformative models of mediation - and the mass processing of cases in civil litigation has often been an uneasy one. Perhaps this model of mediation has been expected to do too much. The recent emergence of new, hybrid processes in the

\footnotetext{
${ }^{195}$ See Goldberg v. Kelly, 397 U.S. 254, 268-69 (1970) ("The opportunity to be heard must be tailored to the capacities and circumstances of those who are to be heard.").

${ }^{196}$ See Boddie v. Connecticut, 401 U.S. 371, 382-83 (1971) (requiring access to courts for indigent parties because states have monopoly on ability to adjust this fundamental human relationship). These procedures also may reflect judicial acknowledgement of the need to adapt to "the exigencies of the circumstances" that burden courts. See Hamdi v. Rumsfeld, 542 U.S. 507, 533-34 (2004) (explaining that exigencies in enemy combatant proceedings might allow "[h]earsay, for example, . . . to be accepted as the most reliable available evidence from the Government").

${ }^{197}$ See Brazil, supra note 131, at 1 (noting importance "for judges to think systematically and carefully" regarding their role in settlement negotiation and providing pros and cons of different formats for settlement conferences); Jean R. Sternlight, The Rise and Spread of Mandatory Arbitration as a Substitute for the Jury Trial, 738 U.S.F. L. REV. 17, 20-21 (2004) (discussing failure of "lawyers, courts, and policy makers" to take sufficient notice of mandatory arbitration's denial of jury trial to claimants); Welsh, Future of Mediation, supra note 193, at 22 (explaining that "the people and government of The Netherlands seem to support the legitimacy of multiple and different, freely-chosen paths to justice . . . [including] dispute resolution paths"); see also Welsh, Making Deals, supra note 46, at 861 ("The experience of justice should not be set aside as some 'sweet old fashioned notion' that has outlived its usefulness to modem, settlementdirected civil litigation. Instead, mediation ... should be allowed to demonstrate that justice can and should have everything to do with the 'world of bargaining' ....").
} 
divorce and child custody area that use the knowledge, expertise, and adjudicative authority of "traditional neutrals" while also incorporating some of mediation's elements-aspects of self-determination, the opportunity for respectful but less formal voice and consideration, the neutral's skillful facilitation of dialogue and mutual consideration between the parties - suggests that bankruptcy judges, repeat players, and policy makers should look at all of their options and their current personnel before settling exclusively upon mediation and mediators as 'the brand new thing' and the only meaningful 'alternative' to traditional litigation.

It is beyond the scope of this Article to examine in detail the efficacy of potential hybrids in the bankruptcy context. Based on the experience of divorce and child custody mediation, however, a few possibilities come to mind. Currently, trustees administer debtors' estates in chapter 7 matters but assume this role in chapter 11 matters only in extreme situations in which creditors have completely lost confidence in the honesty or competence of debtors-in-possession. ${ }^{198}$ Perhaps trustees could play a useful, potentially less intrusive role before situations have become so dire. The procedure of non-confidential dispute resolution and assessment, for example, suggests the possibility that trustees could step in to facilitate negotiations between the debtor and worried creditors, conduct an assessment, interview employees and customers, gather other information, and ultimately make a recommendation to the court before wresting control from the debtor-in-possession. Examiners might be empowered to begin offering a confidential, truncated process in which representatives of the debtor and creditors present their case to two examiners who then provide a tentative recommendation, recognizing that this recommendation is based on the debtor's and creditors' ability to substantiate their claims and defenses. Examiners might even follow this procedure with an opportunity for facilitated negotiation. ${ }^{199}$ Of course, bankruptcy courts would need to ensure that trustees and examiners have sufficient training to play any such new roles and receive appropriate compensation. This presents an obvious challenge, particularly at a time of reduced resources. Outside the courts, some bankruptcy lawyers may wish to explore the application of collaborative or cooperative law to the negotiation of reorganization plans.

These broad brush ideas only begin to suggest the ways in which the divorce and child custody area might offer intriguing potential models that participants in the bankruptcy field may wish to investigate. Obviously, there are significant differences between family law and bankruptcy law. These differences need to be

\footnotetext{
${ }^{198}$ See Edward Janger \& Jeff Ferriell, UNDERSTANDING BANKRUPTCY 143, 151 (2d ed. 2007) (There is no trustee in chapter 11 reorganization cases. Instead, the debtor's estate is administered by the debtor-inpossession, who has all of the same rights, powers, and duties of a trustee. A trustee is appointed only for cause, which includes "fraud, dishonesty, incompetence, or gross mismanagement" of the debtor or its assets, or if the court determines that the appointment of a trustee is "in the interest of creditors"); see also 11 U.S.C. $\S 1104(a)$ (2006) (allowing court to order trustee to be appointed to monitor fraud and mismanagement if it is in best interest of estate and creditors).

${ }^{199}$ See Joshua D. Rosenberg \& H. Jay Folberg, Alternative Dispute Resolution: An Empirical Analysis, 46 STAN. L. REV. 1487, 1489-90 (1994) (articulating purpose of early neutral evaluation process is to encourage both parties to evaluate strength of case, identify areas in dispute, and encourage negotiations).
} 
acknowledged, and, even if a divorce and child custody hybrid looks sufficiently promising to merit investigation and adoption, adaptations almost certainly will be required. ${ }^{200}$ This Article is meant only to stimulate curiosity and encourage further and deeper consideration of the possibilities.

\section{CONCLUSION}

Why should we care about the confusing and conflicting uses of mediation that have surfaced in bankruptcy matters? If the process settles case, why mess with it? The response to this question is two-fold. First and simply, mediation should mean something. People entering into the process should know what to expect, how the mediator will behave toward them, and whether use of their statements and behaviors will be protected by confidentiality or the mediation privilege. Multiple paths to resolution permit parties to choose the path most appropriate to their needs and preferences. ${ }^{201}$

Further, it is only if mediation and mediators have a recognized (and thus valued) function and form that they can play their role and permit other processes and actors to play theirs. Ultimately, the mediation process is then more likely to receive the support it needs in order to fulfill its promise and provide an experience of justice for all of those who participate in it.

Many years ago, Owen Fiss, ${ }^{202}$ Tina Grillo ${ }^{203}$ and Richard Delgado ${ }^{204}$ offered serious critiques of settlement in general and mediation in particular. For reasons that now seem almost sweetly naïve, mediation advocates and program designers thought their (or more accurately, our) good intentions would inoculate mediation from the challenges presented by reality. As a result, some of the fears expressed by Fiss, Grillo and Delgado have been realized. Today, if mediation advocates in the bankruptcy context are willing to learn from others' her/history, they can choose to structure the use of bankruptcy mediation more protectively. Hubris is said to

${ }^{200}$ For example, it would be very important to learn why non-confidential dispute resolution and assessment has been discontinued recently. That information could lead to rejection of this model- or improvement upon it. See Riskin, Understanding Mediators, supra note 37, at 11 (emphasizing mediation techniques cannot be generalized because every dispute or transaction is different and varies greatly within each area of law).

${ }^{201}$ See Shestowsky \& Brett, supra note 76, at 65-66 (noting parties in legal disputes can resolve conflict through negotiation, mediation, trial arbitration, and various other options).

202 Owen Fiss, Against Settlement, 93 YALE L.J. 1073, 1075 (1984) (arguing ADR should not be allowed because parties are often coerced to settle and absence of judicial involvement raises various concerns); see also Against Settlement: Twenty-Five Years Later, 78 FORDHAM L. REV. (forthcoming Dec. 2009).

${ }^{203}$ Tina Grillo, The Mediation Alternative: Process Dangers for Women, 100 YALE L.J. 1045, 1549-50 (1991) (opposing mandatory family mediation because it requires parties to interact in forced setting, women often feel obliged to maintain connection with ex-partner during process, and it is potentially destructive because parties were once involved in intimate relationship).

204 Richard Delgado et al., Fairness and Formality: Minimizing the Risk of Prejudice in Alternative Dispute Resolution, 1985 WIS. L. REV. 1359, 1387-88, 1391 (1985) (stating ADR does little to counter historical and subconscious prejudice, and arguing judicial system should be used to encourage fairness and deter prejudice because such systems are formal, subject to more control, and can reduce prejudice). 
characterize every new generation. Honestly, hubris characterizes every generation, whether young or old. The real question is whether, despite our hubris, we are willing to listen and learn from each other. 